\title{
Ortaokul Ders Kitaplarının Değerlendirilmesi: Bir Dereceli Puanlama Anahtarı
}

\section{Geliştirme Çalışması}

\section{Sinan BÜLBÜL ${ }^{*}$, Buket Özüm BÜLBÜL ${ }^{* *}$}

Öz: $\mathrm{Bu}$ çalışmanın amacı, ortaokul ders kitaplarını değerlendirmeye yönelik bir dereceli puanlama anahtarını geliştirmektir. $\mathrm{Bu}$ amaç kapsamında araştırmacılar tarafından ilgili literatür taranarak ve Millî Eğitim Bakanlığı'nın yayınladığı taslak ders kitabı değerlendirme kriterleri dikkate alınarak bir dereceli puanlama anahtarı oluşturulmuştur. Dereceli puanlama anahtarı hazırlama kriterleri dikkate alınarak oluşturulduktan sonra 2019-2020 eğitim öğretim yılı güz döneminde 39 öğretmen ile iki aşamalı uygulamalar yapılmıştır. Birinci aşamada geçerlik çalışmalarını yürütebilmek için 39 öğretmenden dereceli puanlama anahtarının uygun olup olmadığına yönelik görüşleri alınmıştır. İkinci aşamada ise aralarından seçilen 10 öğretmen ile dereceli puanlama anahtarının güvenirlik analizleri yürütülmüştür. Veriler kapsam geçerliğine bir kanıt oluşturması için kodlayıcılar arasındaki uzlaşma katsayısına, güvenirliğin sağlanması için de Cronbach's Alpha ile puanlayıcılar arasındaki tutarlılık Kendall's W katsayısına bakılarak analiz edilmiştir. Çalışmanın geçerlik ve güvenirlik aşamalarının tamamlanması sonucunda toplam beş boyut 40 göstergeden oluşan, ortaokul ders kitaplarını incelemeye yönelik bir dereceli puanlama anahtarı geliştirilmiştir. Geliştirilen dereceli puanlama anahtarının boyutları; konuya giriş, ölçme ve değerlendirme, bilimsel içerik, dil ve anlatım, görsel tasarım şeklindedir. Çalışma kapsamında geliştirilmiş dereceli puanlama anahtarının ders kitabı seçimi ve değerlendirmelerinde nitelikli ve objektif bir değerlendirme sağlayacağı için tüm branş öğretmenleri tarafından kullanılması önerilmektedir.

Anahtar Kelimeler: Ortaokul ders kitabı, Dereceli puanlama anahtarı, Ders kitabı inceleme, Ölçme aracı geliştirme.

\section{Assessment of Secondary School Textbooks: A Rubric Development Study}

Abstract: The aim of this study is to develop a rubric to assess secondary school textbooks. Within the scope of this purpose, a rubric was developed by the literature review, considering

\footnotetext{
*Dr., Trabzon Üniversitesi Fatih Eğitim Fakültesi, Matematik ve Fen Bilimleri Eğitimi Bölümü, Email: sinanbulbul@gmail.com,Orcid No: 0000-0003-1974-781X

${ }^{* *}$ Dr. Öğr. Üyesi, Manisa Celal Bayar Üniversitesi, Eğitim Fakültesi, Matematik ve Fen Bilimleri Eğitimi Bölümü, Email: cbuketozum@gmail.com, Orcid No: 0000-0001-9610-7053
}

Gönderim:22.01.2021 Kabul:15.03.2021 Yayın:25.05.2021


the draft textbook evaluation criteria published by the Ministry of National Education. After developing the rubric by considering the criteria for preparing, two-stage applications were carried out with 39 teachers in the fall semester of the 2019-2020 academic year. In the first stage, 39 teachers were asked whether the rubric was suitable to carry out the validity studies or not. In the second stage, the reliability analysis of the rubric was conducted with 10 teachers selected among them. The consensus coefficient between encoders was calculated to provide evidence of the content validity of the data. Cronbach's Alpha was calculated to ensure reliability, and consistency between raters was analyzed by looking at Kendall's W coefficient. As a result of the completion of the validity and reliability stages of the study, a rubric was developed for examining secondary school textbooks with a total of five dimensions and 40 indicators. The dimensions of the rubric; introduction for the subject, assessment and evaluation, scientific content, language and expression, visual design. The findings of the study were discussed within the framework of the relevant literature, and suggestions were made for the use of rubric.

Keywords: Secondary school textbooks, Rubric, Textbook examination, Developing an assessment instrument.

\section{Giriş}

Bilim ve teknolojideki hızlı gelişmeler ve bu gelişmeler doğrultusunda ortaya çıkan sistematik düzen olgusu, eğitim-öğretim programlarının yeniden düzenlenerek, bireylere aktarılacak bilgilerin daha sistematik şekilde yapılandırılmasına, dolayısıyla eğitim-öğretim programlarında köklü değişikliklere sebep olmuştur. Eğitim-öğretim programlarına bu doğrultuda hem bireyin hem de toplumun ihtiyaçlarını karşılayarak gelişimini sağlayacak hedefler konulmuştur. Bilgi üreten, yaratıcı ve eleştiren düşünen, problem çözebilen bireylerin yetiştirilmesini amaçlayan eğitim-öğretim programlarının hedeflerinden birisi de tüm bireylere belirtilen unsurların eğitimde eşitlik ilkesine uygun bir şekilde aktarılmasını sağlayacak öğrenme ortamlarının oluşturulmasıdır (Millî Eğitim Bakanlığı [MEB], 2018). Ders kitaplarının öğrenme ortamlarında kullanılması, hem öğrencilerin eşit öğrenmesine firsat vermede hem de soyut kavramları somutlaştırmada yardımcı olabilmektedir. Dolayısıyla ders kitapları öğretim programlarında yer alan hedef, davranış ve kazanımların belirlenen sürede gerçekleştirilmesinde, öğretmenlere kılavuzluk eden öğretim materyalleri arasında yer almaktadır (Akdeniz, 2004; K1lıç, Atasoy, Tertemiz, Şeren ve Ercan, 2001; Turgut, 1996; Yılmaz, Seçken ve Morgil, 1998). Bu kapsamda ders kitaplarının en belirleyici özellikleri; 
öğrencilerin seviyesine uygun olması, ders içeriğinin ayrıntılı bir şekilde sunulması, bilgiler arasında ilişkiler kurabilmesi, öğrencilerin ön bilgilerini harekete geçirmesi ve yeni öğrenilen bilgileri pekiştirmeye firsat tanıması şeklinde sıralanabilir (Alghies ve İncikapı, 2020). Ders kitaplarında belirtilen bu özelliklerin sağlanabilmesi için, sadece mevcut derse ait kazanımlar ve özellikler dikkate alınması yetmeyecektir. Bununla birlikte diğer derslerle olan etkileşimler de söz konusu olduğu için disiplinler arası bir yaklaşım benimsenmelidir. Ek olarak bir öğretim materyalinin geliştirilmesi söz konusu olduğundan, bu materyallere ait genel özellikleri de bünyesinde bulundurabilmesi gerekmektedir. Dolayısıyla farklı branşlardaki ders kitaplarının farklı özelliklerinin olmasının yanında bütün ders kitaplarının sahip olduğu genel özelliklerinden bahsedilebilir. Ders kitaplarının bu özellikleri (a) öğrenilen bilgilerin kalıcılığının sağlanabilmesi, (b) verilen bilgiler arasında ilişkilendirmelerin olması, (c) öğrenciyi derse hazırlamalı, (d) sözlü öğretimde eksik kalan kısımları tamamlaması, (e) öğrenciyi farklı soru tipleri ile karşılaştırmaya fırsat tanıması, (f) öğretimi sıkıcılıktan kurtarması, (g) öğrenciyi aktif düşünen bireyler haline getirmesi şeklindedir (Duman, Karakaya ve Çakmak, 2001).

Etkili bir eğitim öğretim gerçekleştirebilmek için sınıf içi uygulamaların yanında ders kitaplarının doğru şekilde kullanılması da önemlidir. Örneğin bir matematik dersini ele alalım. Eğer bir öğretmen dersi sadece kitapta yer alan örnekleri öğrencilere yöneltiyor, tanımları okuyarak geçiyorsa bu sınıfta gerçekleştirilen öğretim ezberciliğe dayandığından kalıcı öğrenmenin sağlanması oldukça zor olacaktır. Bunun aksine başka bir öğretmen aynı ders için öğrencileri grup oluşturarak etkinlikleri yaptırıyor, kitapta yer alan örnekleri günlük hayatla ilişkilendiriyor ve ölçme değerlendirme bölümlerinde bütün öğrencileri aktif k1lıyorsa bu dersin öğrenme üzerinde daha etkili olduğu söylenebilir. Öğrenme sürecini olumlu ya da olumsuz etkileyen bir diğer faktör de ders kitaplarının doğru bir şekilde hazırlanmasıdır. Genel olarak MEB (2018) tarafından taslak ders kitabı hazırlanma kriterleri belirtilmiş olsa da her branşın farklı öğretim içeriklerinin ve özelliklerinin olması, araştırmacıları son yıllarda ders kitabı değerlendirme çalışmalarına yöneltmiştir (Alkan ve Güven, 2018; Altun, Arslan ve Yazgan, 2004; Aydın ve Şakar, 2020; Bakırcı ve Gülseven; 2018; Bakırcı ve Öçsoy, 2017; Bingölbali ve Bingölbali, 2020; Bütüner, 2020; Caner ve Kurt, 2020; Eroğlu-Doğan, Ekinci ve Doğan, 2020; Fan, 2013; Herbel-Eisenmann, 2007; Kılıç ve Seven, 2002; Kılıçoğlu, 2020; Özkaya ve Duru, 2020; Şirin ve Yıldız, 2020; Üredi ve Ulum, 2020; Yaşar, 2005).

Literatürde ders kitabı incelemeye yönelik çalışmalar incelendiğinde, üç grup altında toplanabilir. Bunları belirli bir branşa yönelik ders kitaplarını incelemeye yönelik (Aydın ve 
Şakar, 2020; Caner ve Kurt, 2020; Eroğlu-Doğan ve diğ., 2020; Şirin ve Y1ldız, 2020; Üredi ve Ulum, 2020), ders kitapları hakkında öğretmen, öğrenci ve veli görüşlerini almaya yönelik (Çelik, Çetinkaya ve Yenmez, 2020; Karabulut ve Öz-Nişli, 2020; Yücel ve Karamustafaoğlu, 2020) farklı ülkelerde yer alan ders kitapları ile Türkiye'deki ders kitaplarını karşılaştırmaya yönelik olmak üzere üç grupta toplayabiliriz (Alghies ve İncikap1, 2020). Örneğin Kılıçoğlu (2020) ortaokul matematik ders kitabı etkinliklerinde soyutlama becerisini incelemiştir. $\mathrm{Bu}$ kapsamda Millî Eğitim Bakanlığı'nca önerilen kitapları inceleyen araştırmacı, matematik öğretim programlarının öğrendiği soyutlama becerilerinin, ders kitaplarında istenilen düzeyde olmadığı sonucuna ulaşmıştır. Dolayısıyla Kılıçoğlu (2020) tarafından yürütülen bu çalışma belirli bir branşa yönelik ders kitaplarını inceleme grubunda yer aldığı söylenebilir. Benzer şekilde Eroğlu-Doğan ve arkadaşları (2020) Fen Bilimleri ders kitapları ile ilgili çalışmaları incelemiştir. Çalışmaları kapsamında toplam 25 lisansüstü tez ve 31 araştırma makalesi inceleyen araştırmacılar, fen bilimleri ders kitaplarını incelemeye yönelik yapılan araştırma makalelerinin, tezlerden daha fazla olduğu, yöntem olarak da daha çok nitel yöntem tercih edildiği sonucuna ulaşmışlardır. Ders kitapları hakkında öğretmen, öğrenci ve veli görüşlerini almaya yönelik çalışmalar kategorisine örnek olarak Çelik ve arkadaşları (2020) tarafından yürütülen ortaokul matematik ders kitaplarının metin okunabilirliği üzerine öğretmen ve öğrenci görüşleri isimli çalışması örnek gösterilebilir. Araştırmacıların 18 matematik öğretmeninden ve 181 öğrenciden görüş alarak yürüttüğü çalışmalarında, ders kitaplarında yer alan günlük yaşamdan örneklerin artırılması gerektiği, yoğun sembol kullanımının azaltılmasının istendiği sonucuna ulaşmıştır. Son olarak farklı ülkelerde yer alan ders kitapları ile Türkiye'deki ders kitaplarını karşılaştırma şeklindeki çalışmalara örnek olarak Alghies ve İncikapı (2020) tarafından yürütülen Libya matematik ders kitaplarının analizine yönelik yapılan çalışma gösterilebilir. Araştırmacılar bu çalışmalarında Libya'da okutulan ders kitaplarının öğretim programları ile uyumlu olduğu sonucuna ulaşmıştır.

Sonuç olarak literatürde ders kitaplarına yönelik yapılan çalışmalar incelendiğinde, ders kitaplarının bazı kriterleri kullanarak değerlendirmede eksik kaldığı düşünülmektedir. Dolayısıyla yukarıda ifade edilen çalışmalarda görüldüğü gibi genel olarak araştırmacılar tarafından seçilen bazı ders kitaplarının belirli bilişsel boyutlarına odaklanılmıştır. Oysa öğretmenler ders kitaplarını seçerken sadece bu bilişsel boyutlara bakmanın yeterli olmadığı görüşüne sahip olabilmektedir. Örneğin matematik ders kitabı seçerken, ders kitabında yer alan örneklerin Bloom taksonomisine göre hangi düzeyde yer aldığı önemli olmakla birlikte tek başına yeterli olamayabilir. Bu durum Matematik, Fen Bilimleri, Türkçe, Bilişim Teknolojileri, 
Din Kültürü ve Ahlak Bilgisi gibi temel dersleri merkeze alarak genel bir ders kitab1 değerlendirmeye yönelik bir dereceli puanlama ölçeğinin oluşturulması ihtiyacını ortaya çıkarmaktadır. Çünkü öğretmenlerin ihtiyacı, genel olarak ders kitaplarını bazı ölçütler doğrultusunda değerlendirebilmek ve bu değerlendirmeler ışığında derslerinde seçeceği kitaba karar vermelerini sağlamaktır. Karar verebilme aşamasına yardımcı olabilecek yöntemlerden biri de ders kitaplarını değerlendirmeye yönelik bir dereceli puanlama anahtarına (DPA) duyulan ihtiyacı ortaya çıkarmaktadır. Bu çalışmada da söz konusu ihtiyacın giderilmesi amaçlandığından, çalışmanın teorik yapısını DPA'nın geliştirmesi oluşturmaktadır.

\section{Dereceli Puanlama Anahtarı}

Dereceli Puanlama Anahtarları (DPA) literatürde rubrik, dereceli puanlama yönergesi, değerlendirme tablosu ve puanlama yönergesi gibi farklı tanımlar içermektedir (Goodrich, 1997). Ancak bu çalışmada DPA kavramı kullanılmıştır. DPA, önceden belirlenmiş ölçütler ile bir çalışmayı değerlendirirken kullanılacak kriterleri sıralayan ayrıntılı bir puanlama rehberidir (Andrade, 2008; Brookhart, 2013; Cooper ve Gargan, 2009; Popham, 1997; Stevens ve Levi, 2005; Wolf ve Stevens, 2007). Bu aşamada dikkat edilmesi gereken şey, DPA'nın sadece bir kontrol listesi ya da değerlendirme ölçeği olarak düşünülmemesinin gerekliliğidir. Çünkü DPA'da yer alan kategorilerinin sayısal olarak belirlenmesinin yanında içerikleri de tanımlanmalıdır (Bülbül, 2019). Diğer bir deyişle DPA'larda kriterler ve bu kriterlerin uygulanma şekline göre puanlamalar yer almaktadır. DPA'ların kullanım amaçları literatürde öz değerlendirme, bireylerin kendi öğrenimlerinin farkında olması, etkili geri dönüt sağlama, bir çalışmanın içeriğinin belirlenmesi gibi farklı şekillerde sıralanmıştır (Andrade, 2008; Benjamin, 2006; Cooper ve Gargan, 2009; Stevens ve Levi, 2005; Tenam-Zemach ve Flynn, 2015). Bu çalışmada ders kitabı incelemeye yönelik bir DPA geliştirmeye yönelik olduğundan “bir çalışmanın içeriğinin belirlenmesi” amacı üzerinde durulmuştur.

DPA'ları geliştirirken literatürde pek çok yöntemden bahsedilmiştir. Bu yöntemler incelenerek Şekil 1'de DPA'nın hazırlanma aşamaları ayrıntılı bir şekilde verilmiştir (Andrade, 2008; Benjamin, 2006; Cooper ve Gargan, 2009; Marzano, Pickering ve McTighe, 1993; Russell ve Airasian, 2001; Stevens ve Levi, 2005). 


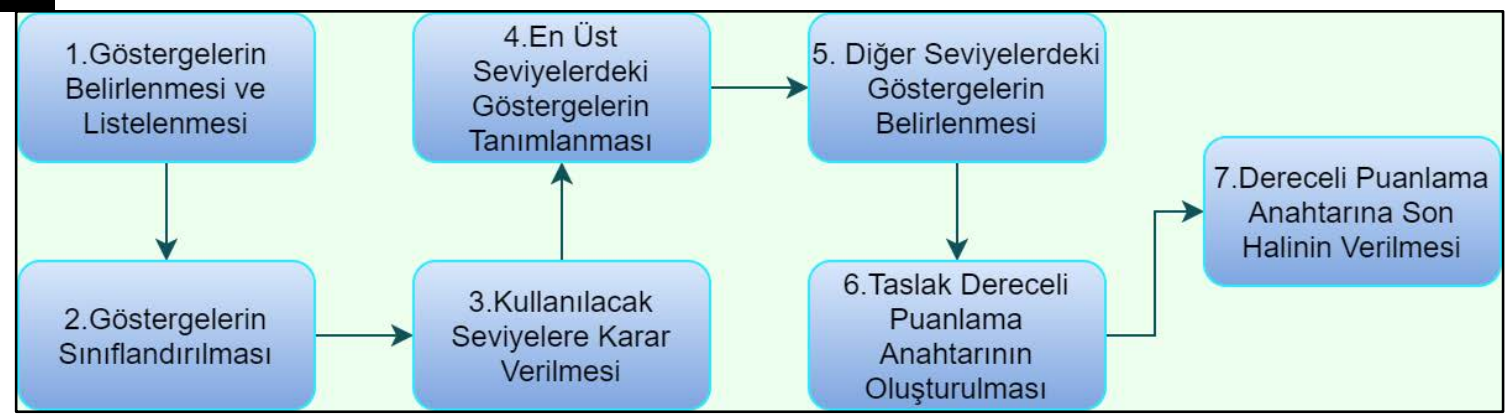

Şekil 1. Dereceli puanlama anahtarı geliştirme aşamaları

Şekil 1 incelendiğinde DPA'ların; göstergelerin belirlenmesi ve listelenmesi, göstergelerin sınıflandırılması, kullanılacak seviyelere karar verilmesi, en üs seviyedeki göstergelerin tanımlanması, diğer seviyelerdeki göstergelerin belirlenmesi, taslak DPA'nın oluşturulması, DPA’ya son halinin verilmesi şeklinde yedi aşamada geliştirildiği görülmektedir. Göstergelerin belirlenmesi ve sınıflandırılması: DPA'larını hazırlamadan önce, değerlendirilecek göstergeler belirlenerek liste haline getirilmelidir. Göstergelerin sınıflandırılması aşamasında benzer davranışları ölçecek nicelikler aynı sınıfa dahil edilerek gruplamalar yapılır. Kullanılacak seviyelere karar verilmesi, belirlenmiş ve sınıflandırılmış göstergelerin kaç farklı seviyede ölçüleceğine karar verilir. Literatürde araştırmacılar genel olarak üç veya beş seviyeyi tercih etmektedir. En üst seviyelerdeki göstergelerin belirlenmesi aşamasında, göstergelerin her birinden en yüksek alınacak puana ve bu puanın neyi ifade ettiğine karar verilir. Diğer seviyelerdeki göstergelerin belirlenmesi: en üst seviyedeki göstergeler belirlendikten sonra diğer seviyelerdeki göstergelere de karar verilir. Taslak DPA'nın oluşturulması: $\mathrm{Bu}$ aşamada artık her şey belirlenmiştir. Yani ölçülmesi istenen göstergeler sınıflandırılmış ve her seviyeden alınan puanın neyi ifade ettiği ayrıntılı bir şekilde yer verilmiştir. $\mathrm{Bu}$ aşamanın en son bölümünde ise taslak DPA tablo haline getirilir. DPA'ya son halinin verilmesi ise taslak DPA'nın geçerlik güvenirlik çalışmalarının yapıldı̆̆ı ve literatüre kazandırıldığg aşamadır.

Literatürde yapılan ders kitaplarına yönelik çalışmalar genel olarak incelendiğinde öğretmenlerin ders kitabı seçerken hangi kriterlere ya da özelliklere dikkat etmeleri gerektiğiyle ilgili önerilerde eksikliklere rastlanmıştır (Bora ve Arslan, 2021; Oktay, Üner ve Şen, 2021; Temel, 2021). Örneğin Matematik ders kitaplarını incelemeye yönelik belirlenen kriterler Fen Bilimleri, Türkçe ya da Sosyal Bilgiler alanında yazılan ders kitabını incelemeye yönelik kriterler bağlamında eksik ya da ilişkisiz kalabilmektedir. Diğer yandan MEB (2018) tarafindan da ifade edildiği gibi eğitim ve öğretimin bir kültür unsuru olduğu ve bu bağlamda ders kitaplarının da ortak bir çatılarının olması gerektiği düşünüldüğünde, bu ders kitaplarının 
değerlendirebilecek bir DPA’ya duyulan ihtiyacı ortaya çıkarmaktadır. Böylece ders kitapları araştırmacılar, öğretmenler ya da ilgili diğer bireyler tarafından kolay bir şekilde değerlendirilebilmesi ders kitaplarının eğitim öğretim sistemimize ait bir kültürü yansıtacak şekilde biçimlendirilmelerine olanak sağlayabilir. Dolayısıyla bu çalışmada ortaokul ders kitaplarını değerlendirmeye yönelik bir DPA'nın geçerlik ve güvenirlik analizleri yapılarak geliştirilmesi amaçlanmaktadır. Bu amaç doğrultusunda araştırmanın ana problemi ve alt problemler aşağıdaki gibidir:

1. Öğretmenlerin ortaokul ders kitaplarını incelemek üzere kullanabilecekleri dereceli puanlama anahtarının özellikleri nelerdir?

- Dereceli puanlama anahtarında bulunması gereken boyut ve göstergeler nelerdir?

- Dereceli puanlama anahtarına ait geçerlik ve güvenirlik özellikleri nelerdir?

\section{Yöntem}

Bu çalışmada ortaokul ders kitaplarını değerlendirmeye yönelik bir DPA tasarlanması amaçlandığından, literatürde yer alan DPA geliştirme aşamaları dikkate alınmıştır. Russell ve Airasian (2011) tarafından tanımlanan yedi aşamalı DPA geliştirme adımları teorik çatı olarak kullanılmıştır. Bu aşamalar; (1) Göstergelerin belirlenmesi ve listelenmesi, (2) Göstergelerin sinıflandırılması, (3) Kullanılacak seviyelere karar verilmesi, (4) En üst seviyelerdeki göstergelerin tanımlanması, (5) Diğer seviyelerdeki göstergelerin belirlenmesi, (6) Taslak DPA'nın oluşturulması, (7) DPA'ya son halinin verilmesi şeklindedir. Bu aşamalara “DPA'nın Geliştirilmesi” başlığı altında ayrıntılı bir şekilde yer verilmiştir.

\section{Çalışma Grubu}

Bu çalışma, amaçlı örnekleme yöntemi kullanılarak 2019-2020 yılları arasında farklı branşlarda ve farklı illerde görev yapan öğretmenler ile yürütülmüştür. Öğretmenler gönüllülük esasına dayalı olarak katılım gösterdiği için, farklı illerdeki öğretmenlere ulaşılmıştır. Ayrıca ders kitabı incelemeye yönelik yapılan çalışmalar incelendiğinde temel derslerde yer alan kitapların (Matematik, Fen Bilimleri, Sınıf, Türkçe ders kitapları gibi) niteliğinin diğer derslerdeki kitaplara nazaran, öğrencilerin başarılarını olumlu etkilediğgi, öğretmenlerin de derslerinde etkili ve verimli kullanabildiğini göstermektedir. Dolayısıyla bu çalışmada oluşturulan DPA, temel ders kitaplarına yönelik olarak hazırlanmış ve bu öğretim seviyesinde ders veren branşlardaki öğretmenlerin katılımı amacına uygun olarak seçilmiştir. Çalışmaya katılan öğretmenlerin sayıları ve branşlarına ilişkin bilgiler Tablo 1'de sunulmuştur. 
Tablo 1. Öğretmenlere Ait Demografik Özellikler

\begin{tabular}{|c|c|c|c|c|c|c|c|}
\hline \multicolumn{8}{|c|}{ Branş } \\
\hline & Bilişim & $\begin{array}{c}\text { Din Kültürü ve } \\
\text { Ahlak Bilgisi }\end{array}$ & Fen Bilimleri & $\begin{array}{l}\text { İlköğretim } \\
\text { Matematik }\end{array}$ & Sinıf & Sosyal & Türkçe \\
\hline Kadın & 2 & 2 & 11 & 9 & 3 & 2 & 3 \\
\hline Erkek & - & 1 & 3 & - & 1 & 1 & 1 \\
\hline Toplam & 2 & 3 & 14 & 9 & 4 & 3 & 4 \\
\hline
\end{tabular}

Tablo 1 incelendiğinde çalışmaya iki Bilişim öğretmeni, üç Din Kültürü ve Ahlak Bilgisi öğretmeni, 14 Fen Bilimleri öğretmeni, dokuz Matematik öğretmeni, dört Sınıf öğretmeni, üç Sosyal Bilgiler öğretmeni ve dört Türkçe öğretmeni olmak üzere toplam 39 ortaokul öğretmeninin katıldığı görülmektedir. DPA'ya ilişkin geçerlik çalışmasının yürütülmesinde her bir branşa yönelik üniversitede görev yapan beş öğretim üyesinden uzman görüşü alınmıştır. Buna ek olarak Tablo 1'de yer alan öğretmenlerden yararlanılarak, DPA için hazırlanan boyutlara ve göstergelere yönelik olarak uygundur ya da uygun değildir şeklinde görüşleri alınmıştır.

Çalışmanın ikinci aşamasında güvenirlik analizleri yürütülmüştür. Bu doğrultuda son hali verilen DPA ile çalışmanın birinci aşamasına katılan öğretmenlerden rastgele seçilmiş 10 öğretmen (Fen Bilimleri, Matematik, Sınıf, Sosyal ve Türkçe branşlarından ikişer öğretmen), kendilerine belirtilen ders kitabındaki konuyu değerlendirmeleri istenmiştir. Elde edilen bu veriler ile DPA'ya ilişkin iç tutarlılık ve puanlayıcı arası tutarlılık analizleri yürütülmüştür.

\section{Dereceli Puanlama Anahtarının Geliştirilmesi}

Çalışmada ders kitaplarını incelemeye yönelik DPA geliştirilirken literatürün bir sentezi olarak hazırlanan ve Şekil 1'de verilen adımlar kullanılmıştır. Aşağıda çalışma kapsamında yapılan işlemler teker teker açıklanmıştır.

1. Göstergelerin Belirlenmesi ve Listelenmesi: Amaç ortaokul ders kitaplarının incelenmesi olduğu için öncelikle bu alana özgü literatür, araştırmacılar tarafından taranmıştır. Araştırmacılar literatürden edindiği bilgileri önce ayrı ayrı listelemiş daha sonra karşılaştırmalar yaparak ortak bir karara varmıştır.

2. Göstergelerin sinıflandırılması: DPA'daki göstergeler listelendikten sonra araştırmacılar tarafından, göstergeleri en iyi temsil edecek sınıflandırmalar yapılmıştır. Sınıflandırma sonucunda her bir göstergeyi en iyi yansıtabilecek toplam beş boyut elde edilmiştir. Bu boyutlar; konuya giriş, ölçme ve değerlendirme, bilimsel içerik, dil ve anlatım, görsel tasarım şeklindedir.

2.1. Konuya Giriş: Konuya giriş boyutu, ders kitaplarında yeni bir konuya başlamadan önce öğrencilerin hazırbulunuşluklarını harekete geçirmeye yöneliktir. Bu kapsamda konuya 
YYÜ Eğitim Fakültesi Dergisi (YYU Journal of Education Faculty), 2021; 18(1)882-911,http://efdergi.yyu.edu.tr,

giriş boyutunda toplam sekiz gösterge yer almaktadır. Göstergeler "günlük hayatla ilişkilendirebilme (KG1), hazırbulunuşluk seviyesine uygunluk (KG2), hazırlık sorularının açık ve anlaşılır olması (KG3), merak uyandırma-dikkat çekicilik (KG4), motivasyon (KG5), araştırma ve inceleme yapmaya teşvik edicilik (KG6), keşfetmeye yönlendirme (KG7), ön bilgileri harekete geçirme (KG8)” şeklindedir.

2.2. Ölçme ve Değerlendirme: Ölçme ve değerlendirme boyutu ders kitaplarındaki ünite sonunda yer alan alıştırmaların, soruların özelliklerine yöneliktir. Bu boyutta toplam 14 gösterge yer almaktadır. Bu göstergeler; “farklı çeşitte soru tiplerinin varliğl (doğru-yanlış, çoktan seçmeli, açık uçlu sorular vb.) (ÖvD1), alternatif ölçme değerlendirme yöntemlerinin varliğl (performans dĕgerlendirmesi, proje ödevi, grup değerlendirmesi, akran değerlendirmesi) (ÖvD2), soru köklerinin anlaşılabilirliği (ÖvD3), ölçme-değerlendirme bölüm yönergelerinin anlaşılırlığ (ÖvD4), sorularda yer alan olumsuz ifadelerin vurgulanması (altı çizili, kalın, italik vb.) (ÖvD5), kısa cevaplı soru-yönerge uyumu (ÖvD6), açık uçlu soru kazanım ilişkisi (ÖvD7), doğru-yanlış soru-yönerge uyumu (ÖvD8), eşleştirmeli soru-yönerge uуuтu (ÖvD9), çoktan seçmeli soru-yönerge uyumu (ÖvD10), cevap anahtarının varlı̆̆ (ÖvD11), öğrenci seviyesine uygunluk (ÖvD12), kazanımlara uygunluk (kazanım seviyesi) (ÖvD13), ünite ögrenme çıtıtlarına uygunluk (tüm ünitede verilen konuları içermesi) (ÖvD14)” şeklindedir.

2.3. Bilimsel Iç̧erik: Bilimsel içerik boyutu ders kitabında yer alan bölümlerin her birinin öğrencilere verdiği içeriklerin özelliklerine yöneliktir. Bu boyut toplam sekiz göstergeye sahiptir. Bu göstergeler “güncellik (Bİ1), ilgi çekicilik (Bİ2), anlaşılabilirlik (Bİ3), öğrenci seviyesine uygunluk (Bİ4), araştırma ve sorgulamaya yönelik olması (Bİ5), bilimsel geçerlik/hata (bilimsel bilgi, teori, teknik, yöntem, terim, birim, sembol vb.) (BÍ6), kavram yanılgısı (Bİ7), ilişkilendirme (günlük hayatla, farklı disiplinlerle, farklı kavramlarla) (Bİ8)” şeklindedir.

2.4. Dil ve Anlatım: Bu boyut ders kitabında kullanılan dilin özellikler bakımından incelenmesini kapsamaktadır. Toplam beş farklı gösterge yer almaktadır. Bu göstergeler “ögrenci seviyesine uygunluk (cümle uzunluğu, söz varlı̆̆l, ifade tarzl, terminoloji, yabancı sözcük vb.) (DA1), kullanılan dilin yapısı (sade, açık, anlaşılır vb.) (DA2), imlâ (özel isim, terim, simge, birim, noktalama işareti vb.) (DA3), anlatım bozukluğu (DA4), özel isimler ve klsaltmalar (DA5)" şeklindedir.

2.5. Görsel Tasarım: DPA'nın görsel tasarım boyutu, kitapta kullanılan resimlerin, grafiklerin şekillerin özellikleri ile ilgilidir. $\mathrm{Bu}$ boyutta toplam beş farklı gösterge yer 
almaktadır. Bu göstergeler "konu ile ilgili şekillerin dikkat çekiciliği (renk, büyüklük, konum vb.) (GT1), görsel öğelerin bölümün amacına uygunluğu (GT2), görsel öğelerin ögrenci seviyesine uygunluğu (şekil/grafik/tablolar, resimler, yazı boyutu, satır aralı̆̆l vb.) (GT3), görsel öğelerin güncelliği (GT4), sayfa tasarımı (renk, yazı tipi, yerleşim, netlik, uyum vb.) (GT5)” şeklindedir.

3. Kullanilacak Seviyelere Karar Verilmesi: DPA'da kullanılacak seviyeye karar verirken iki farklı yol izlenebilir. Bunlardan birincisi her gösterge parçalara ayrılmadan puanlanır (Jackson ve Larkin, 2002). Yani her göstergenin puanlaması ortaktır. Genellikle bütüncül rubriklerde kullanılan yöntemdir. Diğer yöntemde göstergeler bir bütün olarak değil de parça parça alınarak puanlanır (Danielson ve Dragoon, 2016). Genellikle analitik rubriklerde kullanılır. Bu çalışmada da ders kitaplarını incelemeye yönelik hazırlanan DPA'da yer alan her bir ölçüt ilgili göstergeye göre anlam ifade etmektedir. $\mathrm{Bu}$ yüzden genel olarak bütün göstergeler üç seviye oluşturmasına rağmen seviyeler göstergelerin içeriklerine göre farklılık göstermektedir.

4. En Üst Seviyelerdeki Göstergelerin Tanımlanması: DPA hazırlanırken ilk önce göstergelerin en üst düzeyleri belirlenir. Çalışmanın bu aşamasında ilk önce boyutlarda yer alan göstergelerin en üst seviyelerinin (2 puan) ne anlam ifade ettiği belirlenmiştir.

5. Diğer Seviyelerdeki Göstergelerin Belirlenmesi: En üst seviyedeki göstergeler tanımlandıktan sonra diğer göstergelerde yer alan seviyeler de (0 Puan ve 1 Puan) belirlenmiştir. Tablo 2'de her boyutta yer alan göstergelerin bir tanesinden örnek seviyelendirmeye yer verilmiştir.

Tablo 2. DPA’da Kullanılan Göstergelerden Örnekler

\begin{tabular}{|c|c|c|c|c|}
\hline $\begin{array}{c}\text { Boyut } \\
\text { Adı }\end{array}$ & Gösterge & 0 Puan & 1 Puan & 2 Puan \\
\hline 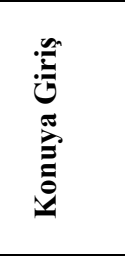 & $\begin{array}{l}\text { Ön bilgileri } \\
\text { harekete } \\
\text { geçirme }\end{array}$ & $\begin{array}{l}\text { Öğrencilerin ön } \\
\text { bilgilerini } \\
\text { harekete geçirici } \\
\text { ifadelere yer } \\
\text { verilmemiştir. }\end{array}$ & $\begin{array}{c}\text { Öğrencilerin ön bilgilerini } \\
\text { harekete geçirici } \\
\text { örnek(ler)e/soru(lar)a/ifade(ler)e } \\
\text { yer verilmiş ancak ön bilgileri } \\
\text { nasıl harekete geçireceğine } \\
\text { yönelik basamaklar açıçca ifade } \\
\text { edilmemiştir. }\end{array}$ & $\begin{array}{c}\text { Öğrencilerin ön bilgilerini harekete } \\
\text { geçirici } \\
\text { örnek(ler)e/soru(lar)a/ifade(ler)e } \\
\text { yer verilmiş ve ön bilgileri nasıl } \\
\text { harekete geçireceğine yönelik } \\
\text { basamaklar açıça ifade edilmiştir. }\end{array}$ \\
\hline 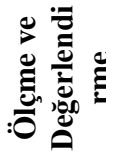 & $\begin{array}{l}\text { Alternatif ölçme } \\
\text { değerlendirme } \\
\text { yöntemlerinin } \\
\text { varlığı }\end{array}$ & $\begin{array}{l}\text { Alternatif ölçme } \\
\text { değerlendirme } \\
\text { yöntemine yer } \\
\text { verilmemiştir. }\end{array}$ & $\begin{array}{l}\text { Tek bir tip alternatif ölçme } \\
\text { değerlendirme yöntemine yer } \\
\text { verilmiştir. }\end{array}$ & $\begin{array}{c}\text { İki ya da daha fazla alternatif } \\
\text { ölçme değerlendirme yöntemine } \\
\text { yer verilmiştir }\end{array}$ \\
\hline 焉 & $\begin{array}{c}\text { İçeriğin } \\
\text { anlaşılabilirliği }\end{array}$ & $\begin{array}{l}\text { İçerikte anlam } \\
\text { belirsizlikleri } \\
\text { vardır. }\end{array}$ & $\begin{array}{l}\text { Anlam belirsizlikleri olmamasına } \\
\text { rağmen öğrenci tek başına içeriği } \\
\text { okuduğunda kafasını } \\
\text { karıştırabilecek unsurlar yer } \\
\text { almaktadır. }\end{array}$ & $\begin{array}{c}\text { İçerik sade, açık ve anlaşılabilir } \\
\text { şekilde sunulmuştur. }\end{array}$ \\
\hline
\end{tabular}




\begin{tabular}{|c|c|c|c|c|}
\hline 焉蓄 & $\begin{array}{l}\text { Kullanılan dilin } \\
\text { yap1s1 }\end{array}$ & $\begin{array}{l}\text { Bölümün dil } \\
\text { yapısı sade, açık } \\
\text { ve anlaşılır } \\
\text { değildir. }\end{array}$ & $\begin{array}{l}\text { Bölümün dil yapısı genel olarak } \\
\text { sade, açık ve anlaşılır şekildedir. }\end{array}$ & $\begin{array}{l}\text { Bölümün tamamında sade, açık ve } \\
\text { anlaşılır bir dil kullanılmıştır. }\end{array}$ \\
\hline 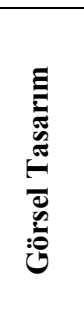 & $\begin{array}{l}\text { Konu ile ilgili } \\
\text { şekillerin dikkat } \\
\text { çekiciliği }\end{array}$ & $\begin{array}{c}\text { Bölümde yer } \\
\text { alan şekiller } \\
\text { rutin, sıradan } \\
\text { olmayan, } \\
\text { öğrencinin } \\
\text { ilgisini } \\
\text { çekmeyecek } \\
\text { özelliklerde } \\
\text { hazırlanmıştır. }\end{array}$ & $\begin{array}{l}\text { Bölümde yer alan şekillerden ilgi } \\
\text { çekicilik özelliklerini } \\
\text { sağlayanların yanında sıradan ve } \\
\text { rutin şekillere de yer verilmiştir. }\end{array}$ & $\begin{array}{c}\text { Bölümde yer alan şekillerin tamamı } \\
\text { öğrencinin dikkatini çekecek } \\
\text { şekilde hazırlanmıştır. }\end{array}$ \\
\hline
\end{tabular}

Tablo 2'de görüldüğü gibi her bir göstergeye ait yapılan seviyelendirme farklı anlamlar ifade etmektedir. Örneğin bilimsel içerik boyutunda yer alan içeriğin anlaşılabilirliği göstergesinde 0 puan: İçerikte anlam belirsizlikleri vardır, 1 Puan: Anlam belirsizlikleri olmamasına rağmen öğrenci tek başına içeriği okuduğunda kafasını karıştırabilecek unsurlar yer almaktadır, 2 Puan: İçerik sade, açık ve anlaşılabilir şekilde sunulmuştur şeklindedir. Buna karşın dil ve anlatım boyutundaki kullanılan dilin yapısı göstergesinde 0 Puan: Bölümün dil yapısı sade, açık ve anlaşılır değildir, 1 Puan: Bölümün dil yapısı genel olarak sade, açık ve anlaşılır şekildedir, 2 Puan: Bölümün tamamında sade, açık ve anlaşılır bir dil kullanılmıştır şeklide seviyelere ayrılmıştır.

6. Taslak DPA'nın Oluşturulması: Bu aşamada ölçülmesi istenen göstergeler sınıflandırılmış ve her seviyeden alınan puanın neyi ifade ettiği ayrıntılı bir şekilde yer verilmiştir. Bu aşamanın en son bölümünde ise taslak derecelendirilmiş puanlama ölçeği tablo haline getirilmiştir. Oluşturulan taslak DPA için uzman görüşü alınmıştır. Uzmanların ve öğretmenlerin verdiği dönütler ile taslak DPA'nın geçerliği sağlanarak güvenirlik analizlerine hazır hale getirilmiştir.

7. DPA'ya Son Halinin Verilmesi: Bu aşamada geliştirilen DPA 39 öğretmenin kullanımına sunulup, belirlenen ders kitabındaki bir üniteyi değerlendirmeleri istenmiştir. Öğretmenlerde elde edilen veriler yardımıyla DPA'nın güvenirlik çalışmaları yapılarak son hali verilmiştir (Bkz. Ek-1). Bu aşamadaki geçerlik ve güvenirlik çalışmalarına ait uygulamalar, verilerin analizi ile bulgular başlıkları altında ayrıntılı bir şekilde belirtilmiştir.

\section{Verilerin Analizi}

$\mathrm{Bu}$ çalışmada ders kitaplarının incelenmesine yönelik DPA'nın geliştirilmesi amaçlandığından geçerlik ve güvenirlik çalışmaları yürütülürken uzman ve öğretmenlerin görüşlerinden yararlanılmış ve ders kitapları puanlanmıştır. Dolayısıyla verilerin analizi iki aşamada yürütülmüştür. 
İlk aşama ders kitaplarını incelemeye yönelik geliştirilen DPA'nın kapsam geçerliğine kanıt oluşturmak amacıyla uzmanların değerlendirmeleri arasındaki uyum incelenmiştir. Bu bağlamda Fen Bilgisi, İlköğretim Matematik, Sınıf, Türkçe öğretmenlikleri bölümlerinde öğretim üyesi olan dört akademisyen ile 39 öğretmenin (Bkz. Tablo 1) DPA’da yer alan boyutlar ve göstergelerin ders kitabı incelemeye uygunluğu, göstergelerin amaçlara ve kapsamlara hizmet edip etmediği, göstergelerde tanımlanan düzeylerin uygunluğu ve bu düzeylerin dil bakımından anlaş1lırlığına ilişkin değerlendirmelerine başvurulmuştur. DPA'da yer alan boyutların ve bu boyutlara ait her göstergenin yanına "uygundur, uygun değildir" şeklinde bir sütun açılmıştır. Uzmanların ve öğretmenlerin uygun değildir başlığını 0 , uygundur başlığını ise 1 rakamı ile kodlamaları istenmiştir. Uygun değildir şeklinde kodlama yapan uzmanlar ve öğretmenler için kodlamalarının hemen altında, maddenin neden uygun olmadığının sebebini açıklaması istenmiştir. Ayrıca aynı kutucuğa söz konusu madde yerine opsiyon olabilecek maddeleri yazması istenmiştir. Dolayısıyla DPA uzman görüşüne sunulmadan öncesi ve sonrasında maddelerde birtakım değişiklikler olmuştur. $\mathrm{Bu}$ değişikliklerden biri toplam beş boyuttan oluşan DPA'nın bazı boyutlarının isimleri revize edilmiştir. Örneğin uzman görüşünden önce ön hazırlık şeklinde ifade edilen boyut, uzman görüşlerinden sonra konuya giriş olarak değiştirilmiştir. Benzer şekilde uzman görüşlerinden önce görsel düzen, tasarım, ilke ve öğeleri şeklinde ifade edilen boyut, uzman görüşünden sonra görsel tasarım olarak revize edilmiştir. Ayrıca uzman görüşlerinden önce konuya hazırlık boyutu 15 maddeden, ölçme ve değerlendirme boyutu 19 maddeden, bilimsel içerik boyutu 13 maddeden, dil ve anlatım boyutu sekiz maddeden, görsel tasarım boyutu ise yedi maddeden oluşmaktaydı. Bazı maddeler aynı anlamı ifade ettiğinden ya da ölçülmesi istenilen özelliği net ifade edemediğinden dolayı uzman görüşleri doğrultusunda revize edilerek DPA'ya son hali verilmiştir. Uzmanların yaptığı kodlamaların hepsi Excel dosyasına aktarıldıktan sonra elde edilen veriler, Miles ve Huberman (1994) tarafindan önerilen güvenirlik formülü kullanılarak hesaplanmıştır. Bu formül aşağıdaki şekildedir:

$$
\text { Güvenirlik }=\frac{\text { Uzlaşma Sayısı }}{\text { Uzlaşma Sayısı }+ \text { Uzlaşmama Sayısı }}
$$

İkinci aşamada, DPA'dan elde edilen puanların güvenirliğini test edebilmek için Cronbach’s Alpha ve Kendall's W katsayıları hesaplanmıştır. Moskal ve Leydens (2000) tarafından da ifade edildiği üzere göstergelere dayalı çoklu puanlamanın yapıldığı bu tür ölçme araçlarında puanlayıcılar arasındaki güvenirlik katsayılarının belirlenmesi önemlidir. Dolayısıyla bu çalışmaya katılan 39 öğretmen arasından farklı branşlardan toplam 10 öğretmen 
seçilmiştir. Bu süreçte her branş için MEB onaylı kitaplar arasından biri belirlenerek bu kitapların ilk ünitelerinin ilk bölümünde yer alan konuları DPA’da yer alan göstergelere göre değerlendirmeleri istenmiştir. Öğretmenlerin kitaplarda yer alan ilgili konuları DPA ile analiz etmeleri sonucunda gerçekleştirilen ölçüme yönelik iç tutarlılık Cronbach's Alpha ile puanlayıcılar arasındaki tutarlılık Kendall's W katsayısı hesaplanarak güvenirlik analizleri gerçekleştirilmiştir.

\section{Araştırmanın Etik Taahhüt Metni}

Yapılan bu çalışmada bilimsel, etik ve alıntı kurallarına uyulduğu; toplanan veriler üzerinde herhangi bir tahrifatın yapılmadığı, karşılaşılacak tüm etik ihlallerde "Yüzüncü Yı1 Üniversitesi Eğitim Fakültesi Dergisi ve Editörünün” hiçbir sorumluluğunun olmadığı, tüm sorumluluğun Sorumlu Yazara ait olduğu ve bu çalışmanın herhangi başka bir akademik yayın ortamına değerlendirme için gönderilmemiş olduğu sorumlu yazar tarafından taahhüt edilmiştir. Ayrıca çalışmanın verileri 2019-2020 Eğitim Öğretim Yılı Güz Dönemi’nde (TR Dizin Kriterlerine göre 2020 yılı öncesinde elde edilen verilerde Etik Kurul İzni alımı zorunlu değildir) toplandığı için Etik Kurul İzni alınmamıştır.

\section{Bulgular}

Ders kitaplarını incelemeye yönelik geliştirilen DPA'ya ait bulgular; geçerliğe ilişkin bulgular, güvenirliğine ilişkin bulgular ve öğretmenlerden elde edilen nitel veriler başlıkları altında sunulmuştur.

\section{DPA'nın Geçerliliğine İlişkin Bulgular}

Ders kitabı inceleme yönelik geliştirilen DPA'nın geçerli bir ölçme aracı olduğunu değerlendirmek amaciyla uzman görüşlerine başvurulmuştur. $\mathrm{Bu}$ doğrultuda uzmanlardan, geliştirilen DAP'da yer alan boyutlar ve bunlara ilişkin göstergelerin ders kitabı incelemeye uygunluğu, göstergelerin amaçlara ve kapsamlara hizmet edip etmediği, tanımlanan düzeylerin uygunluğu ve bu düzeylerin dil bakımından anlaşılırlığına ilişkin görüşleri alınmıştır. Uzmanlardan alınan görüşlerin analizi sonucu uzlaşma yüzdeleri göstergeler için \%76 ile \%94 arasında, boyutlar için ise $\% 81$ ile $\% 98$ arasında değiştiği belirlenmiştir.

\section{DPA'nın Güvenirliğine İliş̧kin Bulgular}

Ders kitabı incelemeye yönelik geliştirilen DPA'nın güvenirlik analizlerinde iç tutarlılığı belirlemek için Cronbach's Alpha katsayısı, puanlayıcılar arasındaki tutarlılığın belirlemek içinse Kendall's W uyuşum katsayısı hesaplanmıştır. İlgili analizler aşağıda verilmiştir. 


\section{İç Tutarlık Katsayısı}

Ders kitabı incelemeye yönelik geliştirilen DPA'nın beş boyutu ve bu boyutlar altında yer alan toplam 40 gösterge için Cronbach's Alpha katsayısı hesaplanmıştır. Analiz sonucunda elde edilen değerler Tablo 3'te gösterilmiştir.

Tablo 3. DPA'nın Cronbach's Alpha Katsayıları

\begin{tabular}{|c|c|c|c|}
\hline Boyut & Gösterge & Madde Toplam Korelasyonu & $\alpha$ \\
\hline \multirow{8}{*}{ Konuya Giriş } & KG1 & .448 & \multirow{8}{*}{.819} \\
\hline & KG2 & .522 & \\
\hline & KG3 & .382 & \\
\hline & KG4 & .462 & \\
\hline & KG5 & 661 & \\
\hline & KG6 & .642 & \\
\hline & KG7 & .602 & \\
\hline & KG8 & .633 & \\
\hline \multirow{14}{*}{ Ölçme ve Değerlendirme } & OvD1 & .535 & \multirow{14}{*}{.755} \\
\hline & OvD2 & .722 & \\
\hline & OvD3 & .337 & \\
\hline & OvD4 & .569 & \\
\hline & OvD5 & .362 & \\
\hline & OvD6 & .393 & \\
\hline & OvD7 & .419 & \\
\hline & OvD8 & .453 & \\
\hline & OvD9 & .312 & \\
\hline & OvD10 & .368 & \\
\hline & OvD11 & .319 & \\
\hline & OvD12 & .714 & \\
\hline & OvD13 & .338 & \\
\hline & OvD14 & .326 & \\
\hline \multirow{8}{*}{ Bilimsel İçerik } & Bi1 & .570 & \multirow{8}{*}{.748} \\
\hline & $\mathrm{Bi} 2$ & .560 & \\
\hline & $\mathrm{Bi3}$ & .332 & \\
\hline & $\mathrm{Bi} 4$ & .396 & \\
\hline & $\mathrm{Bi} 5$ & .533 & \\
\hline & $\mathrm{Bi} 6$ & .660 & \\
\hline & Bi7 & .306 & \\
\hline & $\mathrm{Bi} 8$ & .581 & \\
\hline \multirow{5}{*}{ Dil ve Anlatım } & DA1 & .583 & \multirow{5}{*}{.741} \\
\hline & DA2 & .339 & \\
\hline & DA3 & .576 & \\
\hline & DA4 & .573 & \\
\hline & DA5 & .532 & \\
\hline \multirow{5}{*}{ Görsel Tasarım } & GT1 & .827 & \multirow{5}{*}{.904} \\
\hline & GT2 & .835 & \\
\hline & GT3 & .673 & \\
\hline & GT4 & .821 & \\
\hline & GT5 & .693 & \\
\hline DPA & & & .926 \\
\hline
\end{tabular}

Tablo 3 incelendiğinde, geliştirilen DPA'ın ilk boyutu olan Konuya Giriş için güvenirliğin .819, Ölçme ve Değerlendirme boyutu için .755, Bilimsel İçerik boyutu için .748, Dil ve Anlatım boyutu için .741 ve Görsel Tasarım boyutu için .904 olarak belirlendiği görülmektedir. Beş boyut ve 40 göstergenin tamamı içinse güvenirlik katsayısı 926 olarak belirlenmiştir. Yine Tablo 3'e göre DPA'da yer alan göstergelerin madde toplam korelasyonlarının ise .306 ile .835 arasında değiştiği görülmektedir. 


\section{Puanlayıcı Güvenirliği}

Ders kitabı incelemeye yönelik geliştirilen DPA'nın, puanlayıcılar arası tutarlılığını belirlemek amacıyla Kendall’s W uyuşum katsayı hesaplanmıştır. Analiz sonucunda elde edilen değerler Tablo 4'te gösterilmiştir.

Tablo 4. DPA'nın Kendall's W Uyuşum Katsayıları

\begin{tabular}{cccc}
\hline Boyut & $\mathbf{W}$ & $\chi^{2}$ & $\mathbf{p}$ \\
\hline Konuya Giriş & .897 & 25.118 & $.001^{*}$ \\
\hline Ölçme ve Değerlendirme & .895 & 46.551 & $.000^{*}$ \\
\hline Bilimsel İçerik & .894 & 25.029 & $.001^{*}$ \\
\hline Dil ve Anlatım & .864 & 3.818 & $.008^{*}$ \\
\hline Görsel Tasarım & .895 & 14.316 & $.006^{*}$ \\
\hline DPA & $\mathbf{. 8 7 3}$ & $\mathbf{1 3 6 . 1 5 1}$ & $\mathbf{. 0 0 0}^{*}$ \\
\hline
\end{tabular}

${ }^{*} p<.05$

DPA'nın ilk boyutu olan Konuya Giriş’ten elde edilen puanlar için uyuşum katsayısının $\mathrm{W}=0.897\left(\chi^{2}=25.118 ; \mathrm{p}<0.05\right)$, Ölçme ve Değerlendirme'den elde edilen puanlar için $\mathrm{W}=.895$ $\left(\chi^{2}=46.551 ; \mathrm{p}<0.05\right)$, Bilimsel İçerik’ten elde edilen puanlar için $\mathrm{W}=0.894\left(\chi^{2}=25.029 ; \mathrm{p}<0.05\right)$, Dil ve Anlatım' dan elde edilen puanlar için $\mathrm{W}=0.864\left(\chi^{2}=3.818\right.$; $\left.\mathrm{p}<0.05\right)$ ve son olarak Görsel Tasarım boyutundan elde edilen puanlar için $\mathrm{W}=0.895 \quad\left(\chi^{2}=14.316 ; \mathrm{p}<0.05\right)$ olduğu hesaplanmıştır. DPA'nın tamamından elde edilen puanların uyuşum katsayısı ise $\mathrm{W}=0.873$ $\left(\chi^{2}=136.151 ; \mathrm{p}<0.05\right)$ olarak belirlenmiştir.

\section{Tartışma, Sonuç ve Öneriler}

Bu çalışmada ortaokul ders kitaplarını değerlendirmeye yönelik geçerli ve güvenilir bir DPA'nın geliştirilmesi amaçlanmıştır. Ders kitaplarının incelenmesine yönelik geliştirilen DPA'nın kapsam geçerliğini sağlamak amacıyla uzman görüşleri alınmıştır. Uzmanlara DPA'da yer alan her bir ölçütün yanında uygundur ya da uygun değildir şeklinde görüş bildirmeleri istenmiştir. Bildirilen görüşler doğrultusunda geçerliğe kanıt oluşturmak amacıyla, DPA'nın uyuşum yüzdeleri hesaplanmıştır. Göstergelerin ve boyutların uyuşum yüzdelerinin \%70’ten yüksek çıkması, geliştirilen DPA'nın kapsam geçerliğine uygun olduğunu göstermektedir (Miles ve Huberman, 1994).

Geliştirilen DPA'nın boyutlarına ayrı ayrı bakıldığında güvenirliğin 0.741 ile 0.904 arasında olduğu görülmektedir. DPA'nın tamamı için gerçekleştirilen güvenirlik analizi sonucunda ise Cronbach's alpha katsayısı 0.926 olarak hesaplanmıştır. George ve Mallery (2003) güvenirlik katsayısının 0.70 ve üzerinde olmasının yüksek güvenirliği ifade ettiğini belirtmektedir. Dolayısıyla çalışma kapsamında geliştirilen DPA'yla yapılan ders kitabı 
inceleme analizlerin güvenirliğinin sağlandı söylenebilir. Puanlayıcılar arası güvenirlik katsayısı Kendall's W katsayısı yöntemi ile hesaplanmış ve elde edilen değerler DPA'nın ölçütlerinde puanlayıcılar arası güvenirliğinin yüksek olduğunu göstermiştir (Howell, 2002).

Çalışmanın sonucunda konuya giriş, ölçme ve değerlendirme, bilimsel içerik, dil ve anlatım ile görsel tasarım olmak üzere toplam beş boyuttan ve 40 göstergeden oluşan ortaokul ders kitaplarını incelemeye yönelik bir DPA geliştirilmiştir. Geliştirilen DPA'nın genelinden en düşük 40 puan en yüksek ise 120 puan alınabilmektedir. Boyut bazlı düşünüldüğünde; konuya giriş boyutundan en düşük 8 puan en yüksek 24 puan, ölçme ve değerlendirme boyutundan en düşük 14 puan en yüksek ise 42 puan, bilimsel içerik boyutundan en düşük 8 puan en yüksek 24 puan, dil ve anlatım boyutundan en düşük 5 puan, en yüksek ise 15 puan son olarak görsel tasarım boyutundan en düşük 5 puan en yüksek ise 15 puan alınabilmektedir. Boyut bazlı düşünüldüğünde alınan puanların yüksek olması, değerlendirilmesi yapılan ders kitabının söz konusu boyutta iyi nitelikte olduğu; düşük olması ise o boyutta eksikliklerinin olduğu anlamına gelmektedir. Her bir boyutun bu şekilde değerlendirilmesi yapıldıktan sonra genel DPA puanının yüksek olması, o ders kitabının derslerde uygulanabilecek özellikler taşıdığı anlamına gelmektedir.

Konuya giriş boyutunda yer alan maddelerin madde-toplam korelasyonlarına bakıldığında en yüksek KG5 (merak uyandırma-dikkat çekicilik, motivasyon), KG6 (araştırma ve inceleme yapmaya teşvik edicilik), KG8 (ön bilgileri harekete geçirme) en düşük ise KG3 (hazırlık sorularının açık ve anlaşılır olması) göstergelerinin olduğu görülmektedir. Tavşancıl'a (2010) göre madde-toplam korelasyonlarının 0.30'dan yüksek çıkması maddelerin ölçülen özelliği birbirleriyle tutarlı bir şekilde ölçtüğünü göstermektedir. Bu bulgular her bir ana ölçütteki alt ölçütlerin birbiriyle uyumlu olduğunu ve ilgili oldukları ana ölçütle ölçülmek istenilen beceriyi ölçmeye yönelik olduklarını ortaya koymaktadır. Yani konuya giriş kısmında en çok dikkat çeken ve ölçülmesi tutarlı sonuç veren göstergenin merak uyandırma, dikkat çekicilik ve motivasyon olduğu görülmektedir. Arslan ve Özpınar'ın (2009) altıncı sınıf matematik ders kitaplarının öğretmen görüşleri bağlamında incelenmesine yönelik çalışmasında benzer sonuçlar elde etmiştir. Arslan ve Özpınar (2009) araştırmasının hazırlık çalışmaları boyutunda öğretmenlerin en çok öğrencileri derse karşı dikkat çekmesini ve motive etmesini sağlamaya yönelik olduğunu ifade etmiştir.

Bu çalışmada geliştirilen DPA'nın ölçme ve değerlendirme boyutunun madde toplam korelasyonuna bakıldı̆̆ında en yüksek ÖvD2 (proje ödevi, grup değerlendirmesi, akran değerlendirmesi) ile ÖvD12 (ögrrenci seviyesine uygunluk) olduğu en düşük ise ÖvD9 
(eşleştirmeli soru-yönerge uyumu) olduğu görülmektedir. Elde edilen bu sonuç DPA'ların ölçme değerlendirme kapsamında proje değerlendirmesi, akran değerlendirmesi amaçlarını da ön plana tuttuğunu göstermektedir. Literatürde DPA'ya yönelik yapılan araştırmalar bu çalışmanın ölçme ve değerlendirme boyutundan elde edilen sonuçları destekler niteliktedir (Mullen, 2003; Vaughn, 2002; Schafer, Swanson, Bene ve Newberry, 1999). Bu araştırmalardan biri olan Mullen (2003) çalışmasında DPA'ların öğrencilerin kendilerini değerlendirmeye firsat tanıması, kendi yaptığı ödevleri puanlayarak değerlendirebilmesi gibi amaçlarının olduğunu ifade etmiştir. Mullen'in araştırması bu çalışmanın ölçme değerlendirme boyutu altındaki ÖvD2 göstergesinin madde-toplam korelasyon sayısının yüksek çıkması durumunu destekler niteliktedir.

Geliştirilen DPA'nın bilimsel içerik boyutunun madde toplam korelasyonuna bakıldığında en yüksek B6 (bilimsel geçerlik/hata), Bİ7 (kavram yanılgısı) en düşük ise Bİ8 (ilişkilendirme: günlük hayatla, farklı disiplinlerle, farklı kavramlarla) şeklindedir. Bu durum geliştirilen DPA'nın bilimsel içerik bağlamında en iyi ölçülebilen özelliğin kavram yanılgıları ile bilimsel geçerlik ya da hatalar olduğunu göstermektedir. Pınarbaşı (2002) öğrencilerin öğrenme süreçlerinde kavram yanılgılarının belirlenmesinin öğrenmede etkili olduğunu vurgulaması, bu çalışmada geliştirilen DPA'nın bilimsel içerik boyutundaki göstergenin önemini destekler niteliktedir. Benzer şekilde Yılmaz, Gündüz, Diken ve Çimen (2017) sekizinci sınıf Fen Bilimleri ders kitabının bilimsel içerik bağlamında incelenmesine yönelik çalışmada, bilimsel içerikte kavram yanılgısına yapılan vurguyu destekler niteliktedir.

Çalışmada geliştirilen DPA'nın dil ve anlatım boyutunun madde toplam korelasyonuna bakıldığında en yüksek DA1 göstergesi (kullanılan dilin yapısı: sade, açık, anlaşılır vb.) en düşük ise DA2 göstergesi (imlâ: özel isim, terim, simge, birim, noktalama işareti vb.) olduğu görülmektedir. Son olarak çalışmada geliştirilen DPA'nın görsel tasarım boyutunda yer alan göstergelerin madde-toplam korelasyonlarına bakıldığında en yüksek GT2 (görsel öğelerin bölümün amacına uygunluğu), en düşük ise GT3 (görsel öğelerin öğrenci seviyesine uygunluğu: şekil/grafik/tablolar, resimler, yazı boyutu, satır aralığl vb.) olarak bulunmuştur. Çalışmadan elde edilen bu sonuç Bakırcı ve Gülseven (2018) tarafından yürütülen Fen Bilimleri ders kitabının görsellik bağlamında incelenme durumu ile benzerlik göstermektedir. Araştırmacılar fen bilimleri kitabının parlak, renkli, canlı ve kaliteli kâğıt kullanılarak yapılmasının öğretmenlerin dikkatini çekmede vurgu yaptığını ifade etmiştir.

Sonuç olarak bu çalışmada ortaokul ders kitaplarının değerlendirilmesine yönelik bir dereceli puanlama anahtarı geliştirilmiştir. Ders kitabı incelemeye yönelik yapılan çalışmalara 
bakıldığında temel derslerde yer alan kitapların niteliğinin diğer derslerdeki kitaplara nazaran, öğrencilerin başarılarını olumlu etkilediği, öğretmenlerin de derslerinde etkili ve verimli kullanabildiğini göstermektedir (Arslan ve Özpınar, 2009; Çelik vd., 2020; Karabulut ve ÖzNişli, 2020; Kılıçoğlu, 2020; Şirin ve Yıldız, 2020; Üredi ve Ulum, 2020; Yücel ve Karamustafaoğlu, 2020). Dolayısıyla bu çalışmada geliştirilen DPA'nın Matematik, Fen Bilimleri, Türkçe, Sosyal Bilgiler, Bilişim Teknolojileri, Din Kültürü ve Ahlak Bilgisi ve Sınıf Eğitimi gibi temel ders kitaplarına yönelik olarak hazırlanması araştırmanın sınırlılığını oluşturmaktadır.

Ders kitaplarının öğretimin kalitesini artırabilmesi, öğretimi zenginleştirebilmesi ve her düzeyde öğrencinin eşit öğrenim kazanabilmesi için kabul edilen öğretim programları çerçevesinde hazırlanması gerekir. Ancak Millî Eğitim Bakanlığı tarafından ortak kabul edilen ders kitapları olmasına rağmen öğrenci seviyesinin farklılaşması, okullardaki öğretim standartlarındaki değişim, öğretmen ve öğrencilerin beklentilerindeki farklılık gibi birtakım sebepler ders kitaplarının seçimini oldukça etkilemektedir. Dolayısıyla öğretmenler dönem başında Millı̂ Eğitim Bakanlığı tarafından önerilen kitaplardan birini seçerken, bu çalışmadan elde edilen DPA'yı bir seçim ölçütü olarak kullanılması önerilmektedir. Ayrıca bu çalışmada geliştirilen DPA'nın en önemli özelliği belirli bir alanda yer alan ders kitaplarını incelemekten ziyade, ortaokul düzeyinde yer alan bütün ders kitaplarının değerlendirilmesinde kullanılabilir.

\section{Makalenin Bilimdeki Konumu}

Eğitim Bilimleri, Matematik ve Fen Bilimleri Eğitimi

\section{Makalenin Bilimdeki Özgünlüğü}

Ders kitapları, öğretimi zenginleştiren, öğretimin kalitesini artıran, her öğrenci için eşit düzeyde öğretim gerçekleştirilmesini sağlayan ve ulaşılması en kolay kaynaklardan biridir. Her düzeyde öğrencinin eşit öğrenim kazanabilmesi için de seçilen ders kitaplarının kabul edilen öğretim programları çerçevesinde hazırlanması gerekir. Ancak literatürde ders kitaplarının incelenmesine yönelik yapılan çalışmalar genel olarak incelendiğinde öğretmenlerin ders kitabı seçerken hangi kriterlere ya da özelliklere dikkat etmeleri gerektiğine yönelik önerilerde eksikliklere rastlanmaktadır. Örneğin matematik ders kitaplarını incelemeye yönelik belirlenen kriterler fen bilimleri, Türkçe ya da sosyal bilgiler alanında yazılan ders kitabını incelemeye yönelik kriterler bağlamında eksik ya da ilişkisiz kalabilmektedir. Diğer yandan MEB (2018) tarafından da ifade edildiği gibi eğitim ve öğretimin bir kültür unsuru olduğu ve bu bağlamda ders kitaplarının da ortak bir çatılarının olması gerektiği düşünüldüğünde, bu ders kitaplarının değerlendirebilecek bir DPA'ya duyulan ihtiyacı ortaya çıkarmaktadır. Böylece ders kitapları 
araştırmacılar, öğretmenler ya da ilgili diğer bireyler tarafından kolay bir şekilde değerlendirilebilmesi eğitim öğretim sistemimize ait bir kültürü yansıtacak şekilde biçimlendirilmelerine olanak sağlayabilir. Dolayısıyla bu çalışmadan ortaya çıkan ortaokul ders kitaplarının incelenmesine yönelik geliştirilmiş DPA'nın bu problemi ortadan kaldıracağı düşünülmektedir.

\section{Kaynaklar}

Akdeniz, A. R. (2004). Konu alanı ders müfredatı incelenmesi dersinde yürütülen etkinlikler ve kazandırılan davranışların değerlendirilmesi. Eğitim ve Bilim, 29(134), 11-18.

Alghies, W. M. O. \& İncikabi, L. (2020). Libya matematik ders kitaplarının analizi: İlköğretim yedinci sınıftan dokuzuncu sınıfa. Anadolu Kültürel Araştırmalar Dergisi, 4(3), 295314.

Alkan, S. \& Güven, B. (2018). Ders kitaplarında kullanılan örnek türlerinin analizi: Limit konusu. Türk Bilgisayar ve Matematik Eğitimi Dergisi, 9(1), 147-169.

Altun, M., Arslan, Ç. \& Yazgan, Y. (2004). Lise matematik ders kitaplarının kullanım şekli ve sıklığı üzerine bir çalışma. Uludăg Üniversitesi Eğitim Fakültesi Dergisi, 17(2), 131147.

Andrade, H. (2008). Self-assessment through rubrics. Educational Leadership, 65(4), 60-63.

Arslan, S. \& Özpınar, İ. (2009). İlköğretim 6. sınıf matematik ders kitaplarının öğretmen görüşleri doğrultusunda değerlendirilmesi. Dicle Üniversitesi Ziya Gökalp Eğitim Fakültesi Dergisi, 12, 97-113.

Aydın, Ş. \& Şakar, S. (2020, September). Matematik dersi öğretim programı geometri ve ölçme öğrenme alanları kazanımlarının düşünme becerileri açısından incelenmesi. EJER Congress 2020 Conference Proceeding.

Bakırcı, H. \& Gülseven, E. (2018). 2017 yılında güncellenen ortaokul beşinci sınıf fen bilimleri ders kitabının öğretmen görüşlerine göre değerlendirilmesi. Yüzüncü Yıl Üniversitesi Ĕ̈itim Fakültesi Dergisi, 15(1), 638-671.

Bakırcı, H. \& Öçsoy, K. (2017). Fen bilimleri ders kitaplarında yer alan etkinliklerin girişimcilik bağlamından incelenmesi. Adlyaman Üniversitesi Eğitim Bilimleri Dergisi, 7(2), 256-276.

Benjamin, S. (2006). The quality rubric: A systematic approach for implementing quality principles and tools in classrooms and schools. Milwaukee, Wis: ASQ Quality Press. 
Bingölbali, E. \& Bingölbali, F. (2020). An examination of tasks in elementary school mathematics textbooks in terms of multiple outcomes and multiple solution methods. International Journal of Educational Studies in Mathematics, 7(4), 214-235.

Bora, A. \& Arslan, M. (2021). Türkçe ders $(5,6,7,8)$ kitaplarındaki metinlerin okunabilirlik yönünden incelenmesi. Uluslararası Türkçe Edebiyat Kültür Eğitim (TEKE) Dergisi, 10(1), 222-236.

Brookhart, S. M. (2013). How to create and use rubrics for formative assessment and grading. Alexandria, VA: ASCD Publications.

Bülbül, B.Ö. (2019). How to create and use rubrics? S. Çepni \& Y. Kara (Eds.), Current studies in educational measurement evaluation (pp. 257-268). Çanakkale: Paradigma Akademi.

Bütüner, S. Ö. (2020). Türkiye'de okutulan ortaokul matematik ders kitaplarının aritmetik ortalama kavramına ilişkin öğrencilere sunduğu öğrenme firsatları. Türk Bilgisayar ve Matematik Eğitimi Dergisi, 11(1), 157-187.

Caner, M. \& Kurt, B. (2020). Textbook evaluation approaches. Journal of World of Turks, 12(1), 365-382.

Cooper, B. S. \& Gargan, A. (2009). Rubrics in education: Old term, new meanings. Phi Delta Kappan, 91(1), 54-55.

Çelik, T., Çetinkaya, G. \& Aydoğan-Yenmez, A. (2020). Ortaokul matematik ders kitaplarındaki metinlerin okunabilirliği ve anlaşılabilirliği üzerine öğretmen-öğrenci görüşleri. Ankara Üniversitesi Ĕ̆itim Bilimleri Fakültesi Dergisi, 53(1), 1-28.

Danielson, C. \& Dragoon, J. (2016). Performance tasks and rubrics for upper elementary mathematics. New York: Routledge.

Duman, T., Karakaya, N. \& Çakmak, M. (2001). Konu alanı ders kitabı inceleme kılavuzu (Matematik). Ankara: Nobel Yayınları.

Eroğlu-Doğan, E., Ekinci, R. \& Doğan, D. (2020). Fen bilimleri ders kitapları ile ilgili yapılan çalışmaların incelenmesi. Insan ve Toplum Bilimleri Araştırmaları Dergisi, 9(5), 3479-3499.

Fan, L. (2013). Textbook research as scientific research: towards a common ground on issues and methods of research on mathematics textbooks. ZDM - Mathematics Education, 45(5), 765-777.

George, D. \& Mallery, P. (2003). Using SPSS for windows step by step a simple guide and reference. London: Pearson Education.

Goodrich, H. (1997). Understanding rubrics. Educational Leadership, 54(4), 14-17. 
Herbel-Eisenmann, B. A. (2007). From intended curriculum to written curriculum: Examining the "voice" of a mathematics textbook. Journal for Research in Mathematics Education, 38(4), 344-369.

Jackson, M. \& Larkin, J.M. (2002). Teaching students to use grading rubrics. Teaching Exceptional Children, 35(1), 40-45.

Karabulut, A. \& Öz-Nişli, E. (2020). Özel eğitim uygulama okullarında okutulan ders kitaplarının öğretmenler tarafından incelenmesi. Abant İzzet Baysal Üniversitesi Eğitim Fakültesi Dergisi, 20(4), 1773-1791.

Kılıç, A. \& Seven, S. (2002). Konu alanı ders kitabı incelemesi. Ankara: Pegem A Yayıncılık.

Kılıç, Z., Atasoy, B., Tertemiz, N., Şeren, M. \& Ercan, L. (2001). Öğretimde ders kitaplarının yeri, önemi ve genel özellikleri. L. Küçükahmet (Ed.). Konu alanı ders kitabı inceleme kılavuzu, fen bilgisi (ss. 93-111). Ankara: Nobel Yayın Dağıtım.

Kılıçoğlu, E. (2020). Ortaokul matematik ders kitabı etkinliklerinde soyutlama becerisinin incelenmesi. Mersin Üniversitesi Eğitim Fakültesi Dergisi, 16(3). 628-650.

Marzano, R. J., Pickering, D. \& McTighe, J. (1993). Assessing students outcomes: Performance assessment using the dimensions of learning model. USA: McREL Institute

Miles, M. B. \& Huberman, A. M. (1994). Qualitative data analysis: An expanded sourcebook (2nd ed.). California: Sage Publications, Inc.

Millî Eğitim Bakanlı̆̆ı [MEB]. (2018). Matematik dersi öğretim programı (İlkokul ve ortaokul 1,2,3,4,5,6,7 ve 8. sinıflar). Ankara: Millî Eğitim Bakanlığı Yayınları.

Moskal, B. M. \& Leydens, J. A. (2000). Scoring rubric development: Validity and reliability. Practical Assessment, Research \& Evaluation, 7(10), 1-6.

Mullen, Y. K. (2003). Student improvement in middle school science. (Unpublished Master's Thesis). Wisconsin Oshkosh University, Wisconsin, USA.

Oktay, Ö., Üner, S., \& Şen, A. İ. (2021). Fen bilimleri, fizik, kimya, biyoloji öğretim programları ile ders kitaplarının okul dışı öğrenme yönünden incelenmesi. Mehmet Akif Ersoy Üniversitesi Ĕ̈itim Fakültesi Dergisi, 58, 671-710.

Özkaya, F. ve Duru, A. (2020). Ortaokul matematik ders kitaplarında değerler eğitimi kapsamındaki değerlerin yer alma durumlarının incelenmesi. Uşak Üniversitesi Ĕ̆itim Araştırmaları Dergisi, 6(3), 43-67.

Pınarbaşı, T. (2002). Çözünürlük ile ilgili kavramların anlaşılmasında kavramsal değişim yaklaşımının etkinliğinin incelenmesi. (Yayımlanmamış Doktora Tezi), Atatürk Üniversitesi, Fen Bilimleri Enstitüsü, Erzurum. 
Popham, J. W. (1997). What's wrong and what's right with rubric. Educational Leadership, 55(2), 72-75.

Russell, M. K. \& Airasian, P. W. (2001). Classroom assessment: Concepts and applications. Boston: McGraw-Hill.

Schafer, W. D., Swanson, G., Bene, N. \& Newberry, G. (1999). Effects of teacher knowledge of rubrics on student achievement in four content areas. Applied Measurement in Education, 14(2), 151-170.

Stevens, D. \& Levi, A. (2005). Introduction to rubrics: An assessment tool to save grading time, convey effective feedback, and promote student learning. Sterling, Virginia: Stylus Publishing, LLC.

Şirin, B. \& Yıldız, A. (2020). 8. sınıf matematik ders kitabının PISA temel matematik beceri seviyelerine göre incelenmesi. Cumhuriyet International Journal of Education, 9(4), 1158-1176.

Tavşanc1l, E. \& Aslan, E. (2001). İçerik analizi ve uygulama örnekleri. İstanbul: Epsilon Yayınc1lik.

Temel, S. (2021). Fiziksel ve kimyasal değişme: keskin sınırlarla ayrılabilir mi?. Milli Eğitim Dergisi, 50(229), 545-566.

Tenam-Zemach, M. \& Flynn, J. E. (2015). A rubric nation: Critical inquiries on the impact of rubrics in education. Charlotte, NC: Information Age Publishing.

Turgut, B. (1996). Ders Kitapları ile İlgili Etkinlikler. Türkiye ve Almanya'da Ders Kitapları Sempozyumu, Ankara.

Üredi, L. \& Ulum, H. (2020). İlkokul matematik ders kitaplarında bulunan ünite değerlendirme sorularının yenilenmiş Bloom taksonomisine göre incelenmesi. Mersin Üniversitesi Eğitim Fakültesi Dergisi, 16(2). 432-447.

Vaughn, P. M. (2002). Enhancing student development in service-learning with performancebased assessment rubrics. (Unpublished Doctoral Dissertation), Arizona State University, Arizona, USA.

Wolf, K. \& Stevens, E. (2007). The role of rubrics in advancing and assessing student learning. The Journal of Effective Teaching, 7(1), 3-14.

Yaşar, O. (2005). Türkiye' de okutulan orta öğretim coğrafya ders kitaplarında ölçme ve değerlendirme çalışmalarına yönelik karşılaştırmalı bir yaklaşım. International Journal of Progressive Education, 1(2), 9-30. 
YYÜ Eğitim Fakültesi Dergisi (YYU Journal of Education Faculty), 2021; 18(1)882-911,http://efdergi.yyu.edu.tr,

Yılmaz, A., Seçken, N. \& Morgil, İ. (1998). Lise 11. sınıf kimya 3 ders kitaplarının kimya eğitimine uygunluklarının araştırılması. Hacettepe Üniversitesi Eğitim Fakültesi Dergisi, 14(14), 73-83.

Yılmaz, M., Gündüz, E., Diken, E. \& Çimen, O. (2017). 8. sınıf fen bilimleri ders kitabındaki biyoloji konularının bilimsel içerik açısından incelenmesi. Erzincan Üniversitesi Eğitim Fakültesi Dergisi, 19(3), 17-35.

Yücel, M. \& Karamustafaoğlu, S. (2020). Ortaokul 5. ve 6. sınıf fen bilimleri ders kitapları hakkında öğretmen görüşleri. Amasya Üniversitesi Ĕ̆itim Fakültesi Dergisi, 9(1), 93120. 


\section{Summary}

\section{Statement of Problem}

To perform an effective education, it is important to use the textbooks appropriately in addition to classroom practices. In this context, one of the factors affecting the learning process positively or negatively is the accurate preparation of the textbooks. Although the draft criteria for preparing a textbook were specified by the Ministry of National Education (2018), the fact that each branch has different teaching contents and features have led researchers to textbook evaluation studies in recent years. When the studies about examining the textbooks in the literature are examined, it might be said that the textbooks are incomplete in the evaluation by using some criteria. This deficiency causes difficulties for teachers in choosing textbooks. Because what teachers need is to be able to evaluate the textbooks according to certain criteria and to make them decide on the book they will choose in the light of these evaluations. One of the tools that can assist in the decision-making phase is the need for a rubric for evaluation of textbooks.

\section{Purpose of the Study}

In this study, it is aimed to develop a rubric to assess secondary school textbooks by making validity and reliability analysis.

\section{Method}

Since the aim of this study was to develop a rubric to assess secondary school textbooks, the rubric development such stages as determining and listing the indicators, classifying the indicators, deciding the levels to be used, defining the indicators at the top levels, determining the indicators at other levels, creating the draft graded scoring key, finalizing the rubric were deliberated. In this context, the study was carried out in two stages with a total of 39 teachers. In the first stage, 39 teachers were asked whether the rubric was suitable to carry out the validity studies or not. In the second stage, the reliability analysis of the rubric was conducted with 10 teachers selected among them. The consensus coefficient between encoders was calculated to provide evidence of the content validity of the data. Cronbach's Alpha was calculated to ensure reliability, and consistency between raters was analyzed by looking at Kendall's W coefficient.

\section{Findings and Discussions}

Expert opinions were received to ensure the content validity of the rubric developed for examining the textbooks. Experts were asked to comment on each criterion in the rubric as "suitable" or "not suitable". To provide evidence of validity in the direction of the opinions expressed, the agreement percentages of the rubric were calculated. If the percentage of 
agreement of indicators and dimensions is higher than $70 \%$, it shows that the rubric developed is suitable for the content validity (Miles \& Huberman, 1994).

As a result of the reliability analysis of the developed rubric, it was concluded that the calculated Cronbach Alpha reliability coefficient was high when the dimensions were examined separately and as a whole. Inter-rater reliability coefficient was calculated with the Kendall's W coefficient method, and the values obtained showed that the reliability between raters is high in the rubric's criteria (Howell, 2002). As a result of the study, a rubric was developed to examine middle school textbooks consisting of 40 indicators and five dimensions, including introduction to the subject, assessment and evaluation, scientific content, language and expression, and visual design. When the item-total correlations of the items in the introduction to the subject are examined, the highest indicators are IS5 (curiosity: attention, motivation), IS6 (encouragement to research and investigation), and IS8 (activating prior knowledge); the lowest indicator is IS3 (preparation questions are clear and understandable). When the itemtotal correlations of the items in the assessment and evaluation are examined the highest indicators are AE2 (project assignment, group assessment, peer review) and AE12 (suitability for student level); the lowest indicator is AE9 (matching question-instruction accuracy). When the item-total correlations of the items in the scientific content dimension are examined, the highest indicators are SC6 (scientific validity / error) and SC7 (misconception); the lowest indicator is SC8 (associating with daily life, different disciplines, different concepts). When the item-total correlations of the items in the language and expression dimension are examined, the highest indicator is LE1(structure of the language used: plain, clear, understandable, etc.) and the lowest indicator is LE2 (spelling: proper noun, term, symbol, unit, punctuation, etc.). When the item-total correlations of the items in the visual design dimension are examined, the highest indicator is VD2 (the suitability of visual elements for the purpose of the section) and the lowest indicator is VD3 (the suitability of visual elements to student level: figures / graphics / tables, pictures, font size, line spacing, etc.).

\section{Conclusions and Recommendations}

Textbooks should be prepared within the framework of the accepted curriculum to increase the quality of teaching, to enrich teaching and enable students at all levels to gain equal education. Although there are textbooks that are accepted as common by the Ministry of National Education, some reasons such as the differentiation of student level, the change in the teaching standards in schools, and the difference in the expectations of teachers and students have a great influence on the choice of textbooks. Therefore, when teachers choose one of the 
YYÜ Eğitim Fakültesi Dergisi (YYU Journal of Education Faculty), 2021; 18(1)882-911,http://efdergi.yyu.edu.tr,

books recommended by the Ministry of National Education at the beginning of the semester, it is recommended to use the rubric obtained from this study as a selection criterion. In addition, the most important feature of the rubric developed in this study can be used in the evaluation of all textbooks at the secondary school level, rather than examining the textbooks in a specific field. 


\section{EK-1: Dereceli Puanlama Anahtarı}

\begin{tabular}{|c|c|c|c|}
\hline Konuya Giriş & 0 puan & 1 puan & 2 puan \\
\hline Günlük Hayatla İlişkilendirebilme & $\begin{array}{l}\text { Konuya girişte günlük } \\
\text { hayatla ilişkilendirmeye } \\
\text { yönelik örneklendirme } \\
\text { yapılmamıştır. }\end{array}$ & $\begin{array}{c}\text { Konuya girişte günlük } \\
\text { hayatla ilişkilendirmeye } \\
\text { yönelik örneklendirme } \\
\text { yapılmış ancak örneğe } \\
\text { yönelik detaylı açılama } \\
\text { verilmemiştir. }\end{array}$ & $\begin{array}{c}\text { Konuya girişte günlük } \\
\text { hayatla ilişkilendirmeye } \\
\text { yönelik örneklendirme } \\
\text { yapılmış ve örneğe yönelik } \\
\text { detaylı açılamalara yer } \\
\text { verilmiştir. } \\
\end{array}$ \\
\hline $\begin{array}{c}\text { Hazırbulunuşluk Seviyesine } \\
\text { Uygunluk }\end{array}$ & $\begin{array}{c}\text { Konuya girişte verilen } \\
\text { örnekler/hazırlık } \\
\text { soruları ögrencilerin } \\
\text { hazırbulunuşluk } \\
\text { seviyesine uygun } \\
\text { değildir. }\end{array}$ & $\begin{array}{l}\text { Konuya girişte verilen } \\
\text { örnekler/hazırlık soruları } \\
\text { öğrencilerin hazırbulunuşluk } \\
\text { seviyesine kısmen uygundur. }\end{array}$ & $\begin{array}{l}\text { Konuya girişte verilen } \\
\text { örnekler/hazırlık soruları } \\
\text { öğrencilerin hazırbulunuşluk } \\
\text { seviyesine uygundur. }\end{array}$ \\
\hline $\begin{array}{c}\text { Hazırlık Sorularının Açı ve } \\
\text { Anlaşı1ır Olması }\end{array}$ & $\begin{array}{l}\text { Hazırlık sorularının } \\
\text { tamamı açık ve anlaşılır } \\
\text { değildir }\end{array}$ & $\begin{array}{c}\text { Hazırlık soruları açık ve } \\
\text { anlaşılır olmasına rağmen bir } \\
\text { veya birden fazla } \\
\text { belirsiz/karışı ifade yer } \\
\text { almaktadır. }\end{array}$ & $\begin{array}{l}\text { Hazırlık sorularının tamamı } \\
\text { açık ve anlaşılırdır. }\end{array}$ \\
\hline $\begin{array}{l}\text { Merak Uyandirmak, Dikkat } \\
\text { Çekicilik }\end{array}$ & $\begin{array}{c}\text { Merak uyandırmaya } \\
\text { veya dikkat çekmeye } \\
\text { yönelik } \\
\text { soru/örneklendirme } \\
\text { bulunmamaktadır } \\
\end{array}$ & $\begin{array}{l}\text { Merak uyandırmaya veya } \\
\text { dikkat çekmeye yönelik } \\
\text { sadece bir tane } \\
\text { soru/örneklendirmeye yer } \\
\text { verilmiştir. } \\
\end{array}$ & $\begin{array}{l}\text { Merak uyandırmaya veya } \\
\text { dikkat çekmeye yönelik } \\
\text { birden fazla } \\
\text { soru/örneklendirmeye yer } \\
\text { verilmiştir. }\end{array}$ \\
\hline Motivasyon & $\begin{array}{l}\text { Öğrencileri motive edici } \\
\text { örneklere/sorulara/ifadel } \\
\text { ere yer verilmemiştir. }\end{array}$ & $\begin{array}{l}\text { Öğrencileri motive etmeye } \\
\text { yönelik sadece bir tane } \\
\text { örneğe/soruya/ifadeye yer } \\
\text { verilmiştir. }\end{array}$ & $\begin{array}{l}\text { Öğrencileri motive etmeye } \\
\text { yönelik birden fazla } \\
\text { örneklere/sorulara/ifadelere } \\
\text { yer verilmiştir. }\end{array}$ \\
\hline $\begin{array}{c}\text { Araştırma ve İnceleme Yapmaya } \\
\text { Teşvik Edicilik }\end{array}$ & $\begin{array}{c}\text { Araştırma ve } \\
\text { incelemeye yönelik } \\
\text { herhangi bir } \\
\text { öğeye/örneğe/ödeve yer } \\
\text { verilmemiştir. } \\
\end{array}$ & $\begin{array}{c}\text { Araştırma ve incelemeye } \\
\text { yönelik sadece bir tane } \\
\text { öğeye/örneğe/ödeve yer } \\
\text { verilmiştir. }\end{array}$ & $\begin{array}{c}\text { Araştırma ve incelemeye } \\
\text { yönelik birden fazla } \\
\text { öğeye/örneğe/ödeve yer } \\
\text { verilmiştir. }\end{array}$ \\
\hline Keşfetmeye Yönlendirme & $\begin{array}{l}\text { Öğrencileri keşfetmeye } \\
\text { yönlendirici } \\
\text { örneklere/sorulara/ifadel } \\
\text { ere yer verilmemiştir. }\end{array}$ & $\begin{array}{c}\text { Öğrencileri keşfetmeye } \\
\text { yönlendirici sadece bir tane } \\
\text { örneğe/soruya/ifadeye yer } \\
\text { verilmemiştir. }\end{array}$ & $\begin{array}{c}\text { Öğrencileri keşfetmeye } \\
\text { yönlendirici yönelik birden } \\
\text { fazla } \\
\text { örneklere/sorulara/ifadelere } \\
\text { yer verilmiştir. } \\
\end{array}$ \\
\hline Ön Bilgileri Harekete Geçirme & $\begin{array}{l}\text { Öğrencilerin ön } \\
\text { bilgilerini harekete } \\
\text { geçirici ifadelere yer } \\
\text { verilmemiştir. }\end{array}$ & $\begin{array}{l}\text { Öğrencilerin ön bilgilerini } \\
\text { harekete geçirici } \\
\text { örnek(ler)e/soru(lar)a/ifade(l } \\
\text { er)e yer verilmiş ancak ön } \\
\text { bilgileri nasıl harekete } \\
\text { geçireceğine yönelik } \\
\text { basamaklar açıcça ifade } \\
\text { edilmemiştir. }\end{array}$ & $\begin{array}{c}\text { Öğrencilerin ön bilgilerini } \\
\text { harekete geçirici } \\
\text { örnek(ler)e/soru(lar)a/ifade(l } \\
\text { er)e yer verilmiş ve ön } \\
\text { bilgileri nasıl harekete } \\
\text { geçireceğine yönelik } \\
\text { basamaklar açıkça ifade } \\
\text { edilmiştir. } \\
\end{array}$ \\
\hline
\end{tabular}

\begin{tabular}{|c|c|c|c|}
\hline Ölçme ve Değerlendirme & 0 Puan & 1 Puan & 2 Puan \\
\hline $\begin{array}{l}\text { Farklı Çeşitte Soru Tiplerinin } \\
\text { Varlığı (Doğru-Yanlış, Çoktan } \\
\text { Seçmeli, Açık Uçlu Sorular vb.) }\end{array}$ & $\begin{array}{l}\text { Farklı çeşitte soru tipi } \\
\text { yer verilmemiştir. }\end{array}$ & $\begin{array}{l}\text { İki/Üç çeşit soru çeşidine yer } \\
\text { verilmiştir. }\end{array}$ & $\begin{array}{c}\text { Üçten fazla soru çeşidine yer } \\
\text { verilmiştir. }\end{array}$ \\
\hline $\begin{array}{c}\text { Alternatif Ölçme Değerlendirme } \\
\text { Yöntemlerinin Varlığı } \\
\text { (Performans Değerlendirmesi, } \\
\text { Proje Ödevi, Grup } \\
\text { Değerlendirmesi, Akran } \\
\text { Değerlendirmesi) } \\
\end{array}$ & $\begin{array}{l}\text { Alternatif ölçme } \\
\text { değerlendirme } \\
\text { yöntemine yer } \\
\text { verilmemiştir. }\end{array}$ & $\begin{array}{c}\text { Tek bir tip alternatif ölçme } \\
\text { değerlendirme yöntemine } \\
\text { yer verilmiştir. }\end{array}$ & $\begin{array}{l}\text { İki ya da daha fazla alternatif } \\
\text { ölçme değerlendirme } \\
\text { yöntemine yer verilmiştir. }\end{array}$ \\
\hline Soru Köklerinin Anlaşılabilirliği & $\begin{array}{l}\text { Soruların kurgusu, soru } \\
\text { kökü ve öncülleri açık } \\
\text { ve anlaşılır değildir. }\end{array}$ & $\begin{array}{c}\text { Soruların kurgusu, soru kökü } \\
\text { ve öncüllerinden birinde açık } \\
\text { ve anlaş1lır olmayan unsur } \\
\text { vardır. }\end{array}$ & $\begin{array}{l}\text { Soruların kurgusu, soru kökü } \\
\text { ve öncüllerinin tamamı açık } \\
\text { ve anlaşılırdır. }\end{array}$ \\
\hline
\end{tabular}


Ölçme-Değerlendirme Bölüm Yönergelerinin Anlaşılırlığ

Ölçme ve değerlendirme etkinliklerinin başında bulunan yönergeler açık ve anlaş1lır değildir.

Sorularda Yer Alan Olumsuz İfadelerin Vurgulanması (Altı Çizili, Kalın, İtalik Vb.)

Kısa Cevaplı Soru-Yönerge
Uyumu

Doğru-Yanlış Soru-Yönerge Uyumu

Açık Uçlu Soru - Kazanım İlişkisi

Eşleștirmeli Soru-Yönerge Uyumu

Sorularda yer alan olumsuz ifadelerin hiçbiri vurgulanmamıştır. K1sa cevapli sorularda önemli bilgiyi yoklama, kaynaktan olduğu gibi aktarmama ve ipucuna yer vermeme unsurlarının hiçbiri yerine getirilmemiştir. Açık uçlu soruların hiçbiri ölçülecek

kazanımın kapsamına uygun şekilde sınırlandırılmamıştır. Doğru-yanlış sorularında; belirsizlik içermeme, olumsuz ifade içermeme ve tek bir özelliği ölçme unsurlarının hiçbiri yerine getirilmemiştir. Eşleştirmeli sorularda; cevapların sorulardan fazla olmasi ve soru ile cevapların aynı sayfada yer verilmesi unsurlarının hiçbiri yerine getirilmemiştir. Çoktan seçmeli sorularda; anlaşılır olma, benzer yapıda seçenekler içerme ve seçeneklerde çelişkili ifadeye yer vermeme unsurlarından hiçbiri yerine getirilmemiştir.

Cevap Anahtarının Varlığı
Öğrenci Seviyesine Uygunluk

Cevap anahtarına yer verilmemiştir.

Ölçme ve değerlendirme sorularının yarıdan fazlası öğrenci seviyesine uygun şekilde hazırlanmamıştır.

Ölçme ve değerlendirme sorularının yarıdan fazlası kazanım seviyesine uygun şekilde hazırlanmamıştır. Ölçme ve değerlendirmede yer alan sorular öğrenme çıktılarının hiçbirini ölçmeye yönelik değildir.
Ünite Öğrenme Çıktılarına Uygunluk (Tüm Ünitede Verilen Konuları İçermesi)

Ölçme ve değerlendirme etkinliklerinin başında bulunan yönergelerin bazıları açık ve anlaşılır değildir.

Sorularda yer alan olumsuz ifadelerin bazıları vurgulanmamıştır.

K1sa cevapli sorularda önemli bilgiyi yoklama, kaynaktan olduğu gibi

aktarmama ve ipucuna yer vermeme unsurlarının biri ya da ikisi yerine getirilmemiştir.

Açık uçlu soruların bazıları ölçülecek kazanımın

kapsamına uygun şekilde sınırlandırılmamıştır.

Ölçme ve değerlendirme etkinliklerinin başında

bulunan yönergeler açı ve anlaşılır şekildedir.

Sorularda yer alan olumsuz ifadelerin tamamı vurgulanmıştır.

Kisa cevapli sorularda önemli bilgiyi yoklama, kaynaktan olduğu gibi aktarmama ve ipucuna yer vermeme unsurlarının tamamı yerine getirilmiştir.

Açık uçlu soruların tamamı ölçülecek kazanımın kapsamına uygun şekilde sınırlandırılmıştır.

Doğru-yanlış sorularında; belirsizlik içermeme,

olumsuz ifade içermeme ve tek bir özelliği ölçme unsurlarının biri ya da ikisi yerine getirilmemiştir.

Doğru-yanlış sorularında; belirsizlik içermeme, olumsuz ifade içermeme ve tek bir özelliği ölçme unsurlarının tamamı yerine getirilmiştir.

Eşleştirmeli sorularda; cevapların sorulardan fazla olması ve soru ile cevapların aynı sayfada yer verilmesi unsurlarının birisi yerine getirilmemiştir.

Eşleştirmeli sorularda; cevapların sorulardan fazla olmas1 ve soru ile cevapların aynı sayfada yer verilmesi unsurlarının tamamı yerine getirilmiştir.

Çoktan seçmeli sorularda; anlaşı1ır olma, benzer yapıda seçenekler içerme ve seçeneklerde çelişkili ifadeye yer vermeme

unsurlarından biri ya da ikisi yerine getirilmemiştir.

Çoktan seçmeli sorularda; anlaşılır olma, benzer yapıda seçenekler içerme ve seçeneklerde çelişkili ifadeye yer vermeme unsurlarının tamamı yerine getirilmiştir.

Cevap anahtarında yer alan $\quad$ Cevap anahtarı doğru ve bazı cevaplar yanlış eksiksiz bir şekilde verilmiştir. verilmistir.

Ölçme ve değerlendirme sorularının yarıya yakını öğrenci seviyesine uygun şekilde hazırlanmamıștır.

Ölçme ve değerlendirme sorularının tamamı öğrenci seviyesine uygun şekilde hazırlanmıștır.

Ölçme ve değerlendirme sorularının yarıya yakını kazanım seviyesine uygun şekilde hazırlanmamıştır.
Ölçme ve değerlendirme sorularının tamamı kazanım seviyesine uygun şekilde hazırlanmıştır.
Ölçme ve değerlendirmede yer alan sorular öğrenme çıktılarının yarıya yakınını ölçmeye yönelik değildir.
Ölçme ve değerlendirmede bütün öğrenme çıktılarını ölçen sorulara ver verilmiştir. 


\begin{tabular}{|c|c|c|c|}
\hline Bilimsel İçerik & 0 Puan & 1 Puan & 2 Puan \\
\hline Güncellik & $\begin{array}{l}\text { Bölümde yer alan } \\
\text { içerikler güncel değildir. }\end{array}$ & $\begin{array}{l}\text { Bölümde güncel olmayan } \\
\text { bazı öğeler bulunmaktadır. }\end{array}$ & $\begin{array}{c}\text { Bölümde yer alan içerikler } \\
\text { günceldir. }\end{array}$ \\
\hline İlgi Çekicilik & $\begin{array}{c}\text { Bölümde yer alan } \\
\text { içeriklerde öğrencinin } \\
\text { ilgisini çekici herhangi } \\
\text { bir unsur } \\
\text { bulunmamaktadır. } \\
\end{array}$ & $\begin{array}{l}\text { Bölümde yer alan içeriklerde } \\
\text { öğrencinin ilgisini çekmeyen } \\
\text { bazı öğeler bulunmaktadır. }\end{array}$ & $\begin{array}{c}\text { Bölümde yer alan içeriklerin } \\
\text { tamamı ögrencinin ilgisini } \\
\text { çekici niteliktedir. }\end{array}$ \\
\hline Anlaşılabilirlik & $\begin{array}{l}\text { İçerikte anlam } \\
\text { belirsizlikleri vardır. }\end{array}$ & $\begin{array}{c}\text { Anlam belirsizlikleri } \\
\text { olmamasına rağmen öğrenci } \\
\text { tek başına içeriği } \\
\text { okuduğunda kafasını } \\
\text { karıştırabilecek unsurlar yer } \\
\text { almaktadır. }\end{array}$ & $\begin{array}{l}\text { İçerik sade, açık ve } \\
\text { anlaş1labilir şekilde } \\
\text { sunulmuştur. }\end{array}$ \\
\hline Öğrenci Seviyesine Uygunluk & $\begin{array}{c}\text { Bölümlerde yer alan } \\
\text { kavramlar öğrenci } \\
\text { seviyesine uygun } \\
\text { verilmemiştir. }\end{array}$ & $\begin{array}{c}\text { Bölümlerde yer alan } \\
\text { kavramlardan bazıları } \\
\text { öğrenci seviyesine uygun } \\
\text { değildir. }\end{array}$ & $\begin{array}{l}\text { Bölümlerde yer alan } \\
\text { kavramların hepsi öğrenci } \\
\text { seviyesine uygundur. }\end{array}$ \\
\hline $\begin{array}{c}\text { Araştırma-Sorgulamaya Yönelik } \\
\text { Olma }\end{array}$ & $\begin{array}{l}\text { Bölümde yer alan } \\
\text { içeriklerde öğrenciyi } \\
\text { araştırma-sorgulamaya } \\
\text { yöneltici herhangi bir } \\
\text { unsur bulunmamaktadır. }\end{array}$ & $\begin{array}{c}\text { Bölümde yer alan içeriklerde } \\
\text { öğrenciyi araştırma- } \\
\text { sorgulamaya yöneltecek } \\
\text { unsurlar bulunmasına } \\
\text { rağmen bazı noktalarda } \\
\text { öğrenciyi ezbere } \\
\text { yönelticidir. } \\
\end{array}$ & $\begin{array}{l}\text { Bölümde yer alan içeriklerin } \\
\text { tamamı öğrenciyi araştırma- } \\
\text { sorgulamaya yöneltmektedir. }\end{array}$ \\
\hline $\begin{array}{c}\text { Bilimsel Geçerlik/Hata (Bilimsel } \\
\text { Bilgi, Teori, Teknik, Yöntem, } \\
\text { Terim, Birim, Sembol Vb.) }\end{array}$ & $\begin{array}{c}\text { İçerikte çok fazla } \\
\text { bilimsel geçerliği/hatası } \\
\text { olmayan unsurlar yer } \\
\text { almaktadır. }\end{array}$ & $\begin{array}{l}\text { İçerikte az sayıda bilimsel } \\
\text { geçerliği/hatası olan } \\
\text { unsurlara rastlanmaktadır. }\end{array}$ & $\begin{array}{l}\text { İçerikte bilimsel } \\
\text { geçerliği/hatası olmayan } \\
\text { herhangi bir unsur yoktur. }\end{array}$ \\
\hline Kavram Yanılgis1 & $\begin{array}{c}\text { İçerikte kavram } \\
\text { yanılgısı oluşturabilecek } \\
\text { pek çok ifade yer } \\
\text { almaktadır. } \\
\end{array}$ & $\begin{array}{l}\text { İçerikte kavram yanılgısı } \\
\text { olussturabilecek az sayıda } \\
\text { ifade yer almaktadır. }\end{array}$ & $\begin{array}{l}\text { İçerikte kavram yanılgısı } \\
\text { oluşturabilecek herhangi bir } \\
\text { ifadeye rastlanmamaktadır. }\end{array}$ \\
\hline $\begin{array}{l}\text { İlişkilendirme (Günlük Hayatla, } \\
\text { Farklı Disiplinlerle, Farklı } \\
\text { Kavramlarla) }\end{array}$ & $\begin{array}{c}\text { İçerikte yer alan } \\
\text { ifadelerde herhangi bir } \\
\text { ilişsilendirme unsuru } \\
\text { yoktur. } \\
\end{array}$ & $\begin{array}{l}\text { İçerikte yer alan ifadelerde } \\
\text { az sayıda ilişkilendirme } \\
\text { unsurlarına yer verilmiştir. }\end{array}$ & $\begin{array}{l}\text { İçerikte yer alan ifadelerde } \\
\text { s1k s1k ilişkilendirme } \\
\text { unsurlarına yer verilmiştir. }\end{array}$ \\
\hline Dil ve Anlatım & 0 Puan & 1 Puan & 2 Puan \\
\hline $\begin{array}{c}\text { Öğrenci Seviyesine Uygunluk } \\
\text { (Cümle Uzunluğu, Söz Varlığı, } \\
\text { İfade Tarzı, Terminoloji, Yabancı } \\
\text { Sözcük Vb.) }\end{array}$ & $\begin{array}{l}\text { Bölümün dil ve anlatımı } \\
\text { öğrenci seviyesine } \\
\text { uygun bir şekilde } \\
\text { verilmemiştir. }\end{array}$ & $\begin{array}{l}\text { Bölümün dil ve anlatımında } \\
\text { öğrenci seviyesine uygun } \\
\text { olmayan unsurlar yer } \\
\text { almaktadır. }\end{array}$ & $\begin{array}{l}\text { Bölümün dil ve anlatımı } \\
\text { öğrenci seviyesine uygun bir } \\
\text { şekilde verilmiştir. }\end{array}$ \\
\hline $\begin{array}{c}\text { Kullanılan Dilin Yapısı (Sade, } \\
\text { Açık, Anlaş1lır Vb.) }\end{array}$ & $\begin{array}{l}\text { Bölümün dil yapısı } \\
\text { sade, açık ve anlaşılır } \\
\text { değildir. }\end{array}$ & $\begin{array}{l}\text { Bölümün dil yapısı genel } \\
\text { olarak sade, açık ve anlaşılır } \\
\text { şekildedir. } \\
\end{array}$ & $\begin{array}{c}\text { Bölümün tamamında sade, } \\
\text { açık ve anlaşılır bir dil } \\
\text { kullanılmıştır. }\end{array}$ \\
\hline $\begin{array}{l}\text { İmlâ (Özel İsim, Terim, Simge, } \\
\text { Birim, Noktalama İşareti Vb.) }\end{array}$ & $\begin{array}{c}\text { Bölümde } \\
\text { anlamı/ifadeyi/simge } \\
\text { vb. bozan imlâ hataları } \\
\text { bulunmaktadır. } \\
\end{array}$ & $\begin{array}{c}\text { Bölümde } \\
\text { anlamı/ifadeyi/simge vb. } \\
\text { bozmayan imlâ hataları } \\
\text { bulunmaktadır. }\end{array}$ & $\begin{array}{l}\text { Bölümde herhangi bir imlâ } \\
\text { hatası bulunmamaktadır. }\end{array}$ \\
\hline Anlatım Bozukluğu & $\begin{array}{c}\text { Bölümde bütünlüğü } \\
\text { bozacak pek çok anlatım } \\
\text { bozukluğu } \\
\text { bulunmaktadır. }\end{array}$ & $\begin{array}{c}\text { Bölümde bütünlüğü } \\
\text { bozmayan, bazı anlatım } \\
\text { bozuklukları bulunmaktadır. }\end{array}$ & $\begin{array}{l}\text { Bölümde herhangi bir } \\
\text { anlatım bozukluğu } \\
\text { bulunmamaktadır. }\end{array}$ \\
\hline Özel İsimler ve Kisaltmalar & $\begin{array}{c}\text { Özel isimlerin okunuşu } \\
\text { ve kısaltmaların açılımı } \\
\text { verilmemiştir. }\end{array}$ & $\begin{array}{l}\text { Bölümde bazı özel isimlerin } \\
\text { okunuşları ve kısaltmaların } \\
\text { aç1lımında verilmeyen } \\
\text { ifadeler vardır. }\end{array}$ & $\begin{array}{l}\text { Özel isimlerin okunuşu ve } \\
\text { kısaltmaların açılımı } \\
\text { verilmiştir. }\end{array}$ \\
\hline
\end{tabular}


YYÜ Eğitim Fakültesi Dergisi (YYU Journal of Education Faculty), 2021; 18(1)882-911,http://efdergi.yyu.edu.tr,

\begin{tabular}{|c|c|c|c|}
\hline Görsel Tasarım & 0 Puan & 1 Puan & 2 Puan \\
\hline $\begin{array}{c}\text { Konu ile İlgili Şekillerin Dikkat } \\
\text { Çekiciliği (Renk, Büyüklük, } \\
\text { Konum Vb.) }\end{array}$ & $\begin{array}{l}\text { Bölümde yer alan } \\
\text { şekiller rutin, sıradan } \\
\text { olmayan, öğrencinin } \\
\text { ilgisini çekmeyecek } \\
\text { özelliklerde } \\
\text { hazırlanmıştır. } \\
\end{array}$ & $\begin{array}{c}\text { Bölümde yer alan } \\
\text { şekillerden ilgi çekicilik } \\
\text { özelliklerini sağlayanların } \\
\text { yanında sıradan ve rutin } \\
\text { şekillere de yer verilmiştir. }\end{array}$ & $\begin{array}{c}\text { Bölümde yer alan şekillerin } \\
\text { tamamı öğrencinin dikkatini } \\
\text { çekecek şekilde } \\
\text { hazırlanmıştır. }\end{array}$ \\
\hline $\begin{array}{l}\text { Görsel Öğelerin Bölümün } \\
\text { Amacına Uygunluğu }\end{array}$ & $\begin{array}{l}\text { Bölümde yer alan görsel } \\
\text { öğeler, amaçlara hizmet } \\
\text { etmemektedir. Konu } \\
\text { bağlamı dışında } \\
\text { gereksiz öğelere yer } \\
\text { verilmiştir. }\end{array}$ & $\begin{array}{c}\text { Bölümde yer alan bazı görsel } \\
\text { öğeler amacına uygun } \\
\text { olmasına rağmen konudan } \\
\text { uzak kalmıştır. }\end{array}$ & $\begin{array}{l}\text { Bölümde yer alan görsel } \\
\text { öğelerin tamamı ilgili } \\
\text { konunun amaçlarına uygun } \\
\text { olarak verilmişs; gereksiz, } \\
\text { konu ile ilgisi olmayan } \\
\text { öğelere yer verilmemiştir. }\end{array}$ \\
\hline $\begin{array}{c}\text { Görsel Öğglerin Öğrenci } \\
\text { Seviyesine Uygunluğu } \\
\text { (Şekil/Grafik/Tablolar, Resimler, } \\
\text { Yazı Boyutu, Satır Aralığı Vb.) }\end{array}$ & $\begin{array}{c}\text { Bölümde yer alan görsel } \\
\text { öğeler, öğrenci } \\
\text { seviyesine uygun } \\
\text { değildir. }\end{array}$ & $\begin{array}{l}\text { Bölümde yer alan görsel } \\
\text { öğelerin bazıları öğrenci } \\
\text { seviyesine uygun değildir. }\end{array}$ & $\begin{array}{l}\text { Bölümde yer alan görsel } \\
\text { öğelerin tamamı öğrenci } \\
\text { seviyesine uygun olarak } \\
\text { verilmiştir. } \\
\end{array}$ \\
\hline Görsel Öğelerin Güncelliği & $\begin{array}{l}\text { Bölümde, güncel } \\
\text { olmayan, eski, } \\
\text { alış1lagelmiş görsel } \\
\text { öğeler kullanılmıştır. }\end{array}$ & $\begin{array}{c}\text { Bölümde yer alan görsel } \\
\text { öğeler genellikle güncel } \\
\text { olmakla birlikte bazı eski ve } \\
\text { alış1lagelmiş görsel öğelere } \\
\text { de yer verilmiştir. }\end{array}$ & $\begin{array}{l}\text { Bölümde, farklı örneklerden } \\
\text { seçilmiş güncel görsel } \\
\text { öğelere yer verilmiştir. }\end{array}$ \\
\hline $\begin{array}{l}\text { Sayfa Tasarımı (Renk, Yazı Tipi, } \\
\text { Yerleşim, Netlik, Uyum Vb.) }\end{array}$ & $\begin{array}{l}\text { Bölüm birbiriyle } \\
\text { uyumlu olmayan renk, } \\
\text { yazı tipi, yerleşim, } \\
\text { şekil/resim netliği, } \\
\text { uyum vb. şekilde iyi } \\
\text { düzenlenmemiş sayfa } \\
\text { tasarımına sahiptir. } \\
\end{array}$ & $\begin{array}{l}\text { Bölüm, renk, yazı tipi, } \\
\text { yerleşim, şekil/resim netliği, } \\
\text { uyum vb. unsurların biri ya } \\
\text { da ikisine uygun olmayan bir } \\
\text { sayfa tasarımına sahiptir. }\end{array}$ & $\begin{array}{l}\text { Bölüm, renk, yazı tipi, } \\
\text { yerleşim, şekil/resim netliği, } \\
\text { uyum vb. unsurların } \\
\text { tamamına uygun bir sayfa } \\
\text { tasarımıyla hazırlanmıştır. }\end{array}$ \\
\hline
\end{tabular}

